U. S. DEPARTMENT OF THE INTERIOR

U. S. GEOLOGICAL SURVEY

\title{
DATA RELATED TO CONTAMINANT DISTRIBUTION AT THE BEATTY, NEVADA AND RICHLAND, WASHINGTON LOW-LEVEL \\ RADIOACTIVE WASTE DISPOSAL SITES
}

by

H.G. Wilshire ${ }^{1}$ and Irving Friedman ${ }^{2}$

Open-File Report 97-865

This report is preliminary and has not been reviewed for conformity with U.S. Geological Survey editorial standards or with the North American Stratigraphic Code. Any use of trade, product, or firm names is for descriptive purposes only and does not imply endorsement by the U.S. Government.

1345 Middlefield Road MS/910, Menlo Park, CA 94025

2Denver Federal Center MS/963, Denver, CO 80225 


\title{
DATA ON CONTAMINANT DISTRIBUTION AT THE BEATTY, NEVADA \\ AND RICHLAND, WASHINGTON LOW-LEVEL RADIOACTIVE WASTE DISPOSAL SITES
}

\author{
H.G. Wilshire and Irving Friedman
}

\section{Introduction}

The Beatty, Nevada low-level radioactive waste (LLRW) site was utilized from 1962 to 1992; the Richland, Washington LLRW site was opened in 1965 and remains in use. Both sites accepted hazardous chemical wastes for disposal in separate trenches; disposal of such materials continues at the Beatty site, but not at the Richland site. This report provides a summary of data on the distribution of radioactive and chemical contaminants derived from these facilities. Most of the data are from various regulatory agency, operator, and consultant reports, which are generally of difficult access. More readily accessible newer data and some data not previously published by the authors are included for completeness.

\section{Setting}

Beatty Site. The Beatty site (Fig. 1), located $17 \mathrm{~km}$ south of the town of Beatty, Nevada in the Amargosa Desert, was used for disposal of LLRW from 1962 to 1992 (Conference of Radiation Control Program Directors 1996). A chemical waste disposal facility, opened in 1970 and currently still in use, occupies the eastern half of the site. The site is at the eastern edge of the Holocene flood plain of the Amargosa River, about $3 \mathrm{~km}$ east of the present main river channels, and close to Bare Mountain (Fig. 2). The main channels of the Amargosa River are entrenched about 4-5 m, but braids on the flood plain are likely active during large flood events (Fig. 3). Some larger distributaries of the Amargosa River are located $\sim 0.5 \mathrm{~km}$ west of the site, and smaller ones are intersected by the site boundary (Fig. 2). Some time after early 1994, a large $(\sim 10 \mathrm{~m})$ berm was constructed on the north side of the waste facility by excavating a ditch approximately parallel to the north fence line of the facility (Fig. 4); the ditch extends around the west side of the facility. Runoff from Bare Mountain is channeled east of the LLRW site in a drainage approximately parallel to the Amargosa River.

The eastern part of the LLRW site is located on the edge of a low ridge elongate parallel to U.S. Highway 95 on the east side of the waste facility. The ridge consists in part of upper Proterozoic metamorphic rocks in the lower plate of the Miocene Bare Mountain detachment fault (Hamilton, 1988), surrounded by river gravels that lie above the present flood plain. These alluvial deposits consist dominantly of angular to well-rounded clasts of intermediate and silicic volcanic rocks and lesser proportions of metasedimentary rocks, including minor metadolomite and quartzite. Undissected surfaces have a mature pavement with moderate desert varnish, and may represent abandoned flood plains of older river braids (Warren Hamilton, written comm., 1997). The pavement is underlain by a vesicular A (Av) soil horizon 3-5 cm thick.

The LLRW part of the facility is located on two alluvial units of the Amargosa River flood plain (Swadley and Parrish, 1988), both of which consist of fine-grained reworked eolian sand deposits capped by small pebble lag gravels that form an immature pavement over a 2-3 cm-thick Av soil horizon. The stratigraphy and lithology of sedimentary rocks in the unsaturated zone are known only in outline. Unconsolidated deposits are about $170 \mathrm{~m}$ thick at the site (Nichols, 1987), and the top of the saturated zone is at a depth of about $87 \mathrm{~m}$ in the northeast (Fischer, 1992) and $110 \mathrm{~m}$ in the southwest (Prudic and others, 1997). Johnson (1990), in a study of the chemical waste facility, refers to "upper and lower ground water units" separated by a silt-clay layer on the order of $24 \mathrm{~m}$ thick, but gives no further 
details or evidence of multiple aquifers. The unsaturated zone appears to consist largely or entirely of unconsolidated to weakly indurated deposits, including fluvial, alluvial fan, and marsh valley-fill deposits (Nichols, 1987; Fischer, 1992). Nichols (1987) also reported driller's logs showing "calcareous clay and limestone (?), clay with gravel, and clayey limestone (?)" at depths of about 100 to $120 \mathrm{~m}$. "Clay lenses" were inferred from geophysical logs of monitoring wells 302 (at $\sim 35$ and $\sim 45 \mathrm{~m}$ depth) and 303 (at $\sim 8-10 \mathrm{~m}, \sim 22$ $\mathrm{m}$, and $\sim 25 \mathrm{~m}$ ). The only deposits (inferred from geophysical logs) that correlate among wells 301, 302, and 303 (see Fig. 5) are "marsh (?) deposits" at depths of about 70 to $90 \mathrm{~m}$ (Fischer, 1992). Little information is available on the hydrologic properties of disturbed and undisturbed deposits in the unsaturated zone below $13 \mathrm{~m}$ depth (Nichols, 1987; Fischer, 1992), which is $>2 \mathrm{~m}$ shallower than the deepest disposal trenches (Table 1). Hydrologic properties were reported to depths of $5 \mathrm{~m}$, on samples from which all clasts $>2 \mathrm{~mm}$ across were removed (Andraski, 1996); that study concluded that disturbances from construction and backfilling of waste trenches significantly altered the hydrologic properties of nearsurface materials.

The vegetation community is creosote (Larrea tridentata) scrub and white bursage (Ambrosia dumosa) as codominants, and lesser abundances of spiny hopsage (Grayia spinosa), desert holly (Atriplex hymenelytra), Mormon tea (Ephedra nevadensis), and desert thorn (Lycium andersonii). Creosote shrubs are of small stature, mostly <1 $\mathrm{m}$ height, and spaced between 1 and $8 \mathrm{~m}$ apart; creosote individuals and other shrubs tend to cluster on older geomorphic surfaces. Annual precipitation at the site, dominantly winter rain, averaged $108 \mathrm{~mm}$ in the period 1981-1992 (Andraski, 1996) but was highly variable (range from 136 $\mathrm{mm}$ in 1987 to $14 \mathrm{~mm}$ in 1989). Longer term records indicate an average annual precipitation of $114 \mathrm{~mm}$ at Beatty (158 $\mathrm{m}$ higher elevation than the LLRW site), and $74 \mathrm{~mm}$ at Amargosa Farms, $30 \mathrm{~km}$ southeast of the site and $30 \mathrm{~m}$ lower in elevation (Nichols, 1987).

Richland Site. The Richland LLRW site is in the Pasco Basin on the Columbia River Plateau, and lies within the U. S. Department of Energy's Hanford Reservation in southeastern Washington (Fig. 5). The site opened for low-level radioactive waste in 1965. The disposal site is on an essentially undissected surface, which has a veneer of stabilized (where undisturbed) sand sheets and small dunes (Fig. 6). Regrading of the site and its location near the crest of a gentle rise makes it subject to stormwater runon from the east (U. S. Environmental Protection Agency [USEPA], 1992). Beneath the eolian sand deposits, the section at the Hanford Reservation comprises in descending order: (1) flood deposits of gravel, sand, and silt of the Pleistocene Hanford formation (informally named; $\sim 65 \mathrm{~m}$ thick); (2) gravels that contain less basalt clasts than underlying Ringold gravels and have a quartzofeldspathic sand matrix ( $25 \mathrm{~m}$ thick); and (3) lacustrine clay with thin silt and sand interbeds, overbank laminated to massive silt and silty fine sands with paleosols containing variable amounts of pedogenic carbonate, fluvial quartzo-feldspathic sands and gravels of varied lithologies, and alluvial fan deposits of crudely stratified basaltic detritus of the Miocene-Pliocene Ringold Formation ( $185 \mathrm{~m}$ thick) (Lindsey, 1991; Reidel and others, 1992; Lindsey and others, 1994). Sedimentary rocks of the Ringold Formation lie on basalts of the Columbia River Group.

LLRW site-specific stratigraphic information based on trench exposures (to $14 \mathrm{~m}$ depth) and boreholes (to $\sim 110 \mathrm{~m}$ depth) indicates surficial colluvium, alluvium, dune sands, and interbedded volcanic ash deposits to a depth of $\sim 3-6 \mathrm{~m}, \sim 15-18 \mathrm{~m}$ of well-bedded silt and fine to coarse sand slackwater deposits ("Touchet Beds"), and gravels of the Hanford formation (?) and Ringold Formation to the bottom of the boreholes (USEPA, 1992). Sedimentary rocks of the Hanford formation contain numerous mostly steep dipping clastic dikes from a few centimeters to over a meter thick (Connelly and others, 1992). 
An unconfined aquifer in the Ringold Formation is at a depth of $100 \mathrm{~m}$ (Fig. 5) (Lindsey and others, 1994). Ground water flow paths are toward the Columbia River, some $16 \mathrm{~km}$ distant (Fig. 5). Natural recharge of the aquifer is from rainfall and runoff from surrounding hills, infiltration from small ephemeral streams, and subsurface infiltration from fractures in underlying basalts. Artificial recharge of contaminated liquids has occurred at the 200 West and 200 East sites (Fig. 5) (Connelly and others, 1992; Trent, 1992; Lindsey and others, 1994).

The LLRW site is on the north flank of the Cold Creek syncline in the Yakima fold belt; interbedded basalts and gravels comprising the north flank of the syncline dip gently $\left(\sim 5^{\circ}\right)$ southward (Lindsey and others, 1994); the lower part of the Ringold Formation was folded with the underlying basalts, whereas overlying sedimentary materials are undeformed and fill structural lows in the older rocks (USEPA, 1992). Vegetation is a shrub-steppe community of sagebrush (Artemisia spp), rabbitbrush (Chrysothamnus spp), and antelope bitterbrush (Purshia tridentata), with bluebunch wheatgrass (Agropyron spicatum) and mixtures of nonnative cheatgrass (Bromus tectorum) and native grasses (The Nature Conservancy of Washington, 1996). Average annual precipitation in the period 1951-1980 was $160 \mathrm{~mm}$, $52 \%$ of which fell from November through February. Annual precipitation in this period ranged from 76 to $246 \mathrm{~mm}$ (Kearney, 1989).

\section{Disposal Practices}

Beatty Site. Figure 7 shows the distribution of 22 disposal trenches at the Beatty site. Dimensions and dates of opening and closure are given in Table 1. The Nuclear Regulatory Commission (NRC) (1976) reported that liquid wastes had been disposed directly into trenches from at least June 1966 until Spring 1975 when means for solidification of wastes first became operational (US Ecology, 1990a). NRC (1976, p. 63) cited records of receipt at the facility of approximately $770 \mathrm{~m}^{3}$ of liquid radioactive waste between 1966 and 1975 . Site records reported by Striegl and others (1996) indicate disposal of at least $2,270 \mathrm{~m}^{3}$ of liquid radioactive waste from the date of opening of the facility (1962); estimates range as high as $\sim 2,650 \mathrm{~m}^{3}$.

Individual trenches remained open for periods of 3 to 141 months (Table 1). The average measured annual precipitation at the site, $108 \mathrm{~mm}$ (Andraski, 1996), combined with dimensions and dates of opening and closing of the trenches (Table 1), indicates that the amount of rainfall incident on open trenches totaled $\sim 40,000 \mathrm{~m}^{3}$, and the amount incident on open and closed trenches totaled $\sim 135,000 \mathrm{~m}^{3}$ during the life of the facility (Table 2). An unknown additional amount of rainwater entered the trenches from runoff (photographs in Nevada State archives of a $34 \mathrm{~mm}$ rainstorm on August 15, 1984 show runoff entering over the lip of one trench), and, until 1994, runoff from the Amargosa River flood plain was intercepted by the disposal site.

Richland Site. Figure 8 shows the location of 21 disposal trenches and 5 underground resin tanks at the Richland site. Dimensions and dates of opening and closure of the trenches are given in Table 3. Approximately $480 \mathrm{~m}^{3}$ of poorly documented chemical wastes were disposed in the chemical trench. Staff interviews (NRC, 1976) indicated that past disposal practices for this trench may have included disposal of uncontainerized bulk liquid waste; however, a report prepared for the Washington Department of Ecology (Kearney, 1987) concluded that "[a]ccording to the available information, disposal of free liquid at the site appears to have been very limited; thus the direct movement of nonaqueous waste liquids does not appear to be a release mechanism of concern at this site." 
Wastes were disposed in randomly placed metal drums, fiberboard drums, and cardboard boxes in trenches 1-11A. Mixed radioactive and hazardous wastes, including scintillation fluids comprising toluene, benzene, and xylene, resin wastes, and shielding were disposed in these trenches (USEPA, 1992). Mixed wastes were not disposed at this site after November 1985 , so trenches $11 \mathrm{~B}$ and younger ones contain only radioactive waste, which was disposed in randomly placed steel drums and boxes (USEPA, 1992).

In the late 1960 s five underground steel tanks ranging from $\sim 3,800$ to $75,700 \mathrm{~m}^{3}$ capacity were installed (see Fig. 8) for the purpose of evaporative solidification of resin sludges. This procedure proved unsatisfactory, and resins were not stored in these tanks after the early 1970s. In early 1985, leaks were discovered in one tank resulting in contamination of adjacent soils by loss of $450 \mathrm{~m}^{3}$ of liquids. Pumpable wastes were removed from all tanks, two tanks were removed, and three were filled with concrete. Analyses indicated that both radioactive $\left({ }^{60} \mathrm{Co},{ }^{137} \mathrm{Cs},{ }^{3} \mathrm{H},{ }^{14} \mathrm{C}\right)$ and organic wastes had been stored in the tanks (Kearney, 1987, USEPA, 1992).

\section{Contaminant Distribution}

Beatty Site. Tables 4-6 show the distribution of radioactive contaminants found in ground water beneath and near the Beatty facility. Monitoring of ground water at depths of $\sim 90-110$ $m$ was begun in 1962, and of the unsaturated zone in 1963 (Conference of Radiation Control Program Directors, 1996). Gross alpha and gross beta above action levels ${ }^{1}$ ( $30 \mathrm{pCi} / \mathrm{L}$ and 90 $\mathrm{pCi} / \mathrm{L}$, respectively) were first discovered in ground water in 1970 ; tritium $\left({ }^{3} \mathrm{H}\right)$ above detection levels in ground water was first observed in 1970, and levels exceeding action levels $(2,000 \mathrm{pCi} / \mathrm{L})$ were first documented in 1979 (Table 4). An internal Nuclear Regulatory Commission memorandum dated April 22, 1985, noted, in addition to high 1983 ${ }^{3} \mathrm{H}$ in ground water in wells 301 and 302 , "[h]igh coliform bacteria counts in site ground water, ... [r]adium-225 up to $18 \mathrm{pCi} /$, [c] ]hromium and [b]arium up to almost $1 \mathrm{mg} /$," suggesting leakage from the site septic system as well as from the chemical and radioactive waste trenches. Soils from the shallow unsaturated zone were sampled from dry wells near the disposal trenches and the four corners of the site. Dry wells were mostly located at the south side of completed trenches, and were dug to depths of at least $3.0 \mathrm{~m}$ below the bottom of the trench (see Table 1). Two dry wells were located south of the site, and additional offsite surface samples were obtained about $60 \mathrm{~m}$ from the site to the N, E, SE, and W (Conference of Radiation Control Program Directors, 1996). Gross alpha counts exceeding action levels in soils were first detected in 1975, and gross beta counts in 1972 (Table 4).

Tritium contamination in an offsite borehole close to the LLRW site (see Fig. 7, UZB-2) was documented in samples collected from near the surface to depths to $94 \mathrm{~m}$ in the unsaturated zone in 1992-1996, and ${ }^{14} \mathrm{C}$ in samples collected to depths of $\sim 45 \mathrm{~m}$ in 19941995 (Table 6; Fig. 9) (Prudic and Striegl, 1995; Striegl and others, 1996; Prudic and others, 1997). Tritium concentrations have increased throughout the period of measurement, to concentrations to $64,000 \mathrm{pCi} / \mathrm{L}$ at a depth of $1.7 \mathrm{~m}, 4,300 \mathrm{pCi} / \mathrm{L}$ at $49 \mathrm{~m}$, and $2,500 \mathrm{pCi} / \mathrm{L}$ at $94 \mathrm{~m}$ in $1996 .{ }^{14} \mathrm{C}$ activity also increased between 1994 and 1995 (Striegl and others, 1996).

Vegetation (not identified) showed no gross alpha values in excess of action levels (20 $\mathrm{pCi} / \mathrm{g}$ ), but gross beta exceeded action levels ( $200 \mathrm{pCi} / \mathrm{g})$ in 1972, 1974, and 1976 (Table 6).

\footnotetext{
1 "Action levels" are defined by the Conference of Radiation Control Program Directors (1996). Reporting level values are cited here in the absence of reliable data on ambient levels of the constituents, and thus may or may not represent an anthropogenic addition to the natural system.
} 
Tritium contamination (Table 6) of identified off-site vegetation to levels greater than 30,000 $\mathrm{pCi} / \mathrm{L}$ was reported by Striegl and others (1996).

Approximately $1,135 \mathrm{~m}^{3}$ of phosphoric acid sludge was disposed directly into trenches in the chemical waste facility (Jacobs Engineering Group, 1987; USEPA, 1987). This practice ceased in 1973 when phosphoric liquid contaminant was detected in a 12-m deep observation well. Emplacement of 20 observation wells and test holes revealed a plume of phosphoric acid contamination with a vertical extent between 0.6 and $2.4 \mathrm{~m}$; the plume extended southward beyond the site boundary approximately 5 to $8 \mathrm{~m}$ by 1973 . Concentrations of the contaminants are not known (Jacobs Engineering Group, 1987; USEPA, 1987), nor is it known whether further migration has occurred since 1973.

A report prepared for the USEPA (Johnson, 1990; see also, USEPA, 1987) indicated that vapor and "shallow ground water" samples collected between 1988 and 1992 show widespread contamination by volatile organic compounds derived from the chemical waste. Contamination of the "upper water-bearing zone" was detected in monitoring wells 308-311 and 316 (Fig. 7) at the eastern and southern perimeter of the chemical waste facility. Contamination of the "lower water-bearing zone" was detected in monitoring well 307 within the chemical waste area (Fig. 7).

Richland Site. Much less information is available on contaminant distribution at the Richland site than at Beatty. Five ground-water-monitoring wells (Fig. 8, Nos. 003, 005, 008,010 , and 013) were installed in 1985 . Well 013 is at the western edge of the site, upgradient from the trenches for ground water flow. Data obtained from 1986 through 1996 (Table 8) show relatively elevated levels of ${ }^{3} \mathrm{H}$ in ground water throughout the monitoring period. All wells show similar patterns of ${ }^{3} \mathrm{H}$ concentration with time, first decreasing through 1989, then increasing progressively through 1996 (Fig. 10). G. Robertson, State of Washington Department of Health (written comm., 1997), believes that the upgradient well (013) is affected by the leading edge of a tritium-rich plume from the 200 West Area (Fig. 11), but this is not supported by ${ }^{3} \mathrm{H}$ concentrations of similar magnitude (Table 8) in upgradient well 013 and downgradient well 003 , or the position(s) of the tritium plume(s) from the 200 West and 200 East Areas (Fig. 11). Delaney and Lindsey (1991) indicate further that the ground water flow direction from 200 West is northeast, and that from 200 East is northwest, both away from the LLRW site (Fig. 12).

Three test holes (Fig. 8, VW-100, 101, and 102) were drilled in 1991 to monitor the unsaturated zone (US Ecology, 1992a). VW-100 was drilled in the NW corner of the site to serve as a control. Pore water from core samples taken from an $11 \mathrm{~m}$ interval at the bottom of each well was analyzed for ${ }^{3} \mathrm{H}$ (Table 9), showing very low concentrations in samples from VW-100. VW-101 shows ${ }^{3} \mathrm{H}$ concentrations from 2,000 to $28,000 \mathrm{pCi} / \mathrm{L}$, with a maximum at a depth of $14 \mathrm{~m}$, whereas VW-102 has a maximum of $55,000 \mathrm{pCi} / \mathrm{L}$ of ${ }^{3} \mathrm{H}$ at a depth of $10 \mathrm{~m}$, the shallowest level sampled (Fig. 12). Subsequent vapor sampling from 1993 to 1996 (Table 10) indicates maximum values for the 4 years ranging from 700 to 1,700 $\mathrm{pCi} / \mathrm{L}$ (VW-100), 239,000 to $337,000 \mathrm{pCi} / \mathrm{L}$ (VW-101), and 450,000 to $497,000 \mathrm{pCi} / \mathrm{L}$ (VW102). Solar stills installed at the locations of the VW wells, and sampling vapor from depths of $46 \mathrm{~cm}$, gave results like those of the VW boreholes (Table 10). The unsaturated zone monitoring wells sample the entire $11 \mathrm{~m}$ screened interval (US Ecology, 1992a). The maximum depth of sampling for each well is $25.6 \mathrm{~m}$ (VW-100), $17.4 \mathrm{~m}(\mathrm{VW}-101)$, and 21.3 $\mathrm{m}(\mathrm{VW}-102)$. 
Details of the extent and nature of unsaturated zone contamination from leakage of the resin tanks, in which ${ }^{60} \mathrm{Co},{ }^{137} \mathrm{Cs},{ }^{3} \mathrm{H},{ }^{14} \mathrm{C}$, among other anthropogenic constituents, were identified, are not reported (Kearney, 1987; USEPA, 1992).

Tritium contents of trench-cap vegetation for the period 1987 to 1996 are given in Table 12. Values reported range from less than detection level (one sample) to $4,270,000 \mathrm{pCi} / \mathrm{L}$. Because of this variability, alternative analytical procedures are being investigated (Conference of Radiation Control Program Directors, 1996).

\section{Acknowledgments}

We thank Bruce Rogers and Jane Nielson, U.S. Geological Survey for assistance in preparation of line-drawings, and Warren Hamilton, Colorado School of Mines, and G.I. Smith and K.A. Howard, U.S. Geological Survey, for reviews of the manuscript.

\section{References}

Andraski, B. J., 1996, Properties and variability of soil and trench fill at an arid waste-burial site: Journal of the Soil Science Society of America, v. 60, p. 54-66.

Conference of Radiation Control Program Directors Inc., 1996, Environmental monitoring report for commercial low-level radioactive waste disposal sites (1960's through 1990's): National Low-Level Waste Management Program, DOE/LLW-241, 176 pp.

Connelly, M. P., Borghese, J. V., Delaney, C. D., Ford, B. H., Lindberg, J. W., and Trent, S. J., 1992, Hydrogeologic model for the 200 East groundwater aggregate area:

Westinghouse Hanford Co., WHC-SD-EN-TI-019.

Delaney, C.D., and Lindsey, S.P., 1991, Geology and hydrology of the Hanford Site-A standardized text for use in Westinghouse Hanford Company documents and reports: Westinghouse Hanford Co., WHC-SD-ER-TI-003.

Fischer, J. M., 1992, Sediment properties and water movement through shallow unsaturated alluvium at an arid site for disposal of low-level radioactive waste near Beatty, Nye County, Nevada: U S Geological Survey Water-Resources Investigations Report 924032, $48 \mathrm{pp}$.

Hamilton, W. B., 1988, Detachment faulting in the Death Valley region, California and Nevada, in M. D. Carr, J. C. Yount (eds), Geologic and hydrologic investigations of a potential nuclear waste disposal site at Yucca Mountain, southern Nevada: U. S. Geological Survey Bulletin 1790, p. 51-85.

Jacobs Engineering Group Inc., 1987, RCRA facility assessment of solid waste management units at US Ecology Inc Beatty Nevada disposal site: EPA Region 9, No. NVT330010000 , TES IV Contract, Work Assignment 262, 39 pp.

Johnson, R. L., 1990, A review of organic contaminants in the unsaturated zone and groundwater zones at the Beatty, Nevada TSD site. Prepared for USEPA, 8 pp.

Kearney, A. T., 1987, Closure and perpetual care and maintenance of the commercial lowlevel radioactive waste disposal facility on the Hanford Reservation-Phase I report, prepared for Washington Department of Ecology, 104 pp. 
Kearney, A. T., 1989, Closure and perpetual care and maintenance of the commercial lowlevel radioactive waste disposal facility on the Hanford Reservation-Phase II report, prepared for Washington Department of Ecology, $177 \mathrm{pp}$.

Lindsey, K. A., 1991, Revised stratigraphy for the Ringold Formation, Hanford site, southcentral Washington: Westinghouse Hanford Co., WHC-SD-EN-EE-004.

Lindsey, K. A., Reidel, S. P., Fecht, K. R., Slate, J. L., Law, A. G., and Tallman, A. M., 1994, Geohydrologic setting of the Hanford site, south-central Washington, in Swanson, D. A. and Haugerud, R. A. (eds.), Geologic field trips in the Pacific northwest: Geological Society of America, Annual Meeting, Chapt 1C, 16 pp.

Nichols, W. D., 1987, Geohydrology of the unsaturated zone at the burial site for low-level radioactive waste near Beatty, Nye County, Nevada: U S Geological Survey WaterSupply Paper 2312, 57 pp.

Nuclear Regulatory Commission, 1976, Final inspection report by Region V Office of Inspection and Enforcement, in response to information of extensive removal of radioactive materials from the Beatty disposal site, $68 \mathrm{pp}$.

Prudic, D. E., Stonestrom, D. A., and Striegl, R. G., 1997, Tritium, deuterium, and oxygen18 in water collected from unsaturated sediments near a low-level radioactive-waste burial site south of Beatty, Nevada: U S Geological Survey Water-Resources Investigations Report 97-4062, 23 pp.

Prudic, D. E. and Striegl, R. G., 1995, Tritium and radioactive carbon $\left({ }^{14} \mathrm{C}\right)$ analyses of gas collected from unsaturated sediments next to a low-level radioactive-waste burial site south of Beatty, Nevada, April 1994 and July 1995: U.S. Geological Survey OpenFile Report 95-741, 7 pp.

Reidel, S. P., Lindsey, K. A., and Fecht, K. R., 1992, Field trip guide to the Hanford Site: Westinghouse Hanford Company, WHC-MR-0391, 50 pp.

Striegl, R. G., Prudic, D. E., Duval, J. S., Healy, R. W., Landa, E. R., Pollock, D. W., Thorstenson, D. C., and Weeks, E. P., 1996, Factors affecting tritium and ${ }^{14}$ carbon distributions in the unsaturated zone near the low-level radioactive-waste burial site south of Beatty, Nevada: U S Geological Survey Open-File Report 96-110, 16 pp.

Swadley, W. C. and Parrish, L. D., 1988, Surficial geologic map of the Bare Mountain quadrangle, Nye County, Nevada: U S Geological Survey Misc Geol Investigations, Map I-1826, 1:48,000 scale.

The Nature Conservancy of Washington, 1996, Biodiversity inventory and analysis of the Hanford site, Annual Report: The Nature Conservancy, Seattle, Washington, 55 pp.

Trent, S. J ., 1992, Hydrogeologic model for the 200 West groundwater aggregate area. Westinghouse Hanford Company, WHC-SD-EN-TI-014, 284 pp..

US Ecology, 1988, Annual environmental monitoring report at US Ecology's low level radioactive waste disposal facility for 1987, US Ecology, Richland, Washington.

US Ecology, 1989, Annual environmental monitoring report at US Ecology's low level radioactive waste disposal facility for 1988: US Ecology, Richland, Washington. 
US Ecology, 1990a, Historical environmental monitoring report, US Ecology low-level radioactive waste disposal facility: US Ecology, Beatty, Nevada.

US Ecology, 1990b, Annual environmental monitoring report at US Ecology's Low Level Radioactive Waste Disposal Facility for 1989: US Ecology, Richland, Washington.

US Ecology, 1991, 1990 Annual environmental monitoring report, Richland, Washington LLRW Disposal Facility, US Ecology, Richland, Washington.

US Ecology, 1992a, Vadose zone monitoring program, US Ecology, Richland, Washington, Document 224-DOC-001, Rev. 0.

US Ecology, 1992b, Annual environmental monitoring report for calendar year 1991, US Ecology, Richland, Washington.

US Ecology, 1993a, Annual environmental monitoring report for calendar year 1992, US Ecology, Richland, Washington.

US Ecology, 1993b, Annual environmental monitoring report for calendar year 1993, US Ecology, Richland, Washington.

US Ecology (1994) Annual environmental monitoring report for calendar year 1993, US Ecology, Richland.

US Ecology, 1995, Annual environmental monitoring report for calendar year 1995, US Ecology, Richland, Washington.

US Ecology, 1996, Annual environmental monitoring report for calendar year 1996, US Ecology, Richland, Washington.

U. S. Environmental Protection Agency, 1987, Evaluation of US Ecology facility, Beatty, Nevada: U.S. Environmental Protection Agency, EPA 700-8-87-016, 55 pp.

U. S. Environmental Protection Agency, 1992, Hanford site, US Ecology, Inc, Richland, Washington: RCRA Facility Assessment Report, 23 pp.

Washington State Department of Health, 1993, 1991 Annual Report, Environmental Radiation Program, 260 pp. 


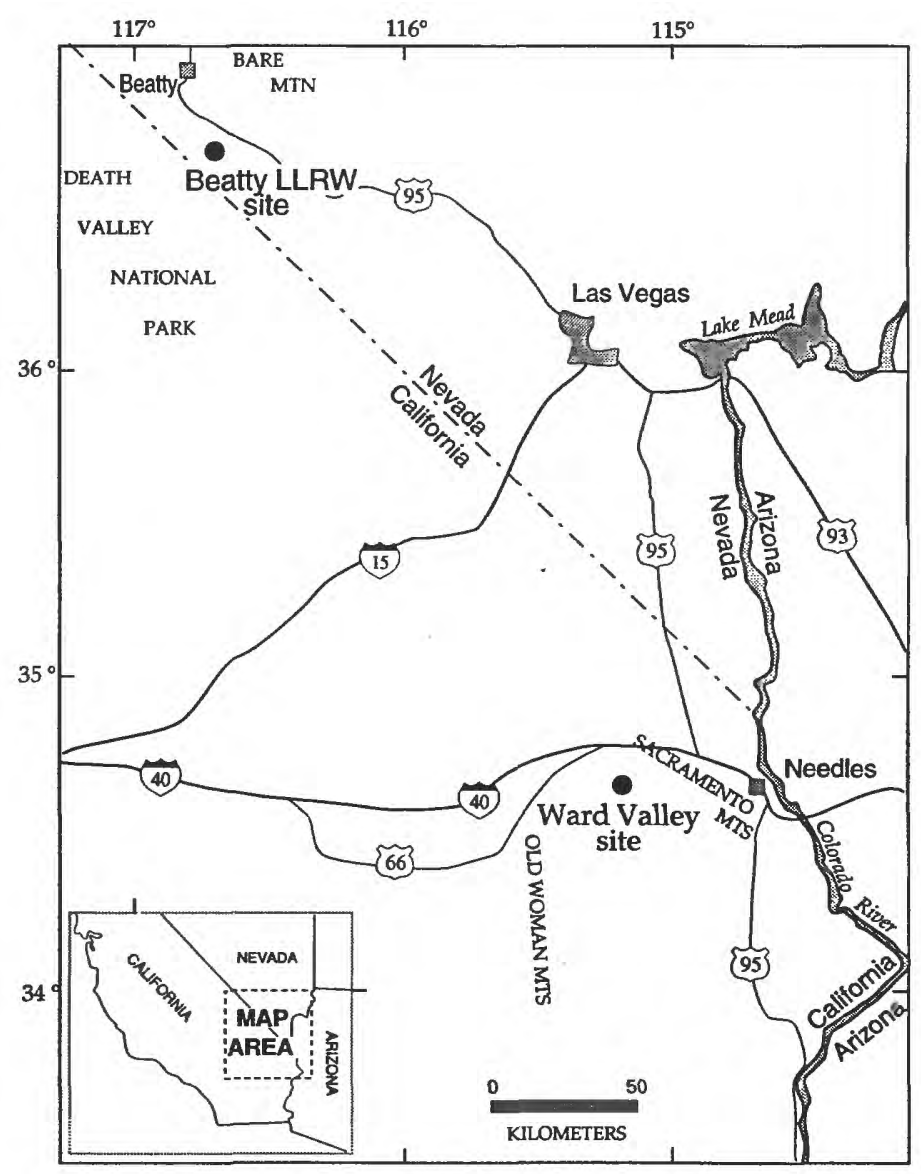

Fig. 1. Map showing location of the Beatty, Nevada LLRW site. 


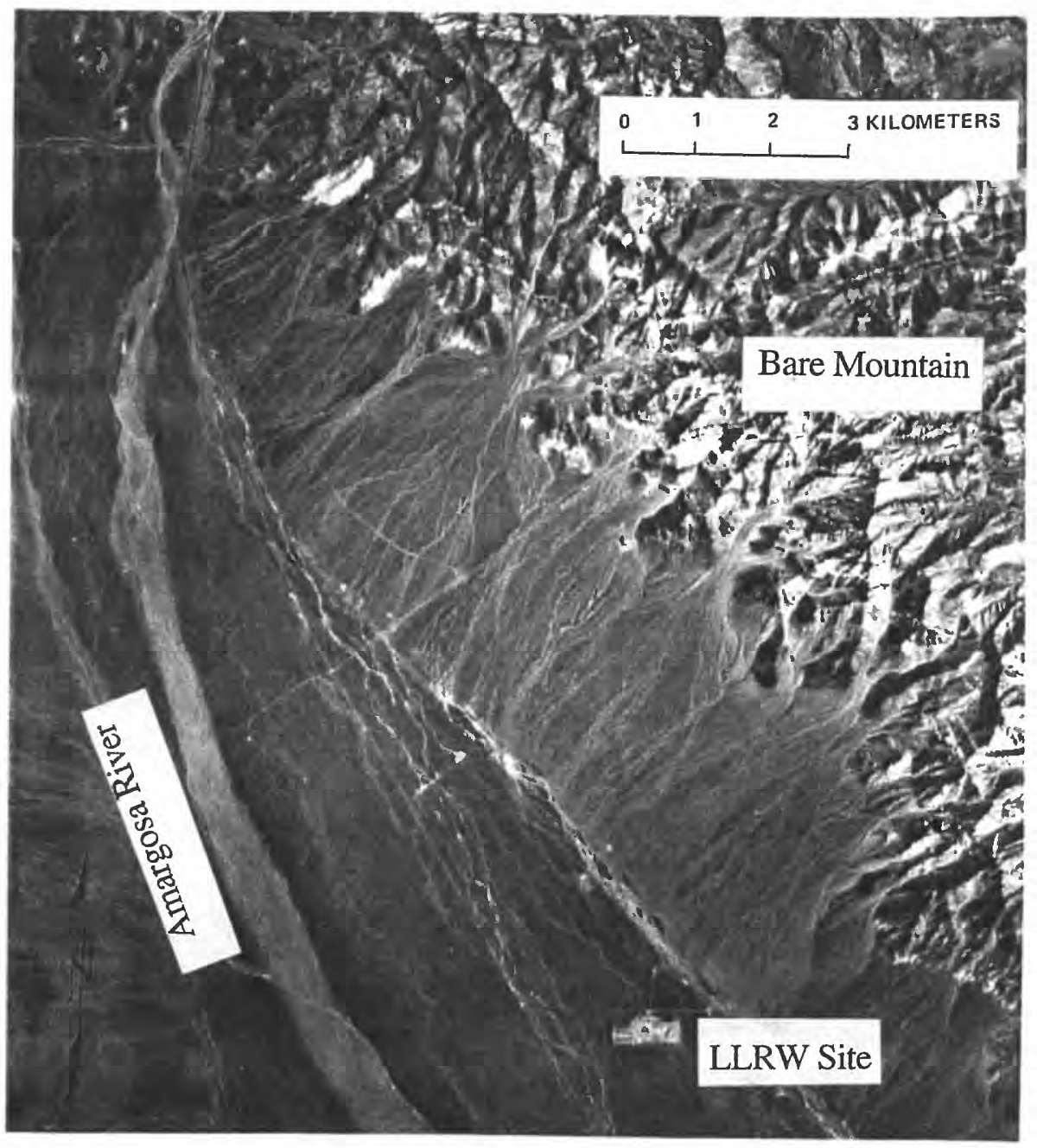

Fig. 2. Aerial photograph showing the Beatty, Nevada LLRW site, and its position on the Amargosa River flood plain. Main Amargosa River channel on left, subsidiary channels concentrated just west of LLRW site. Note that LLRW site intercepts small flood plain channels. The flood plain is a Holocene erosional surface cut in late Pleistocene valley fill. Photograph 1976. 


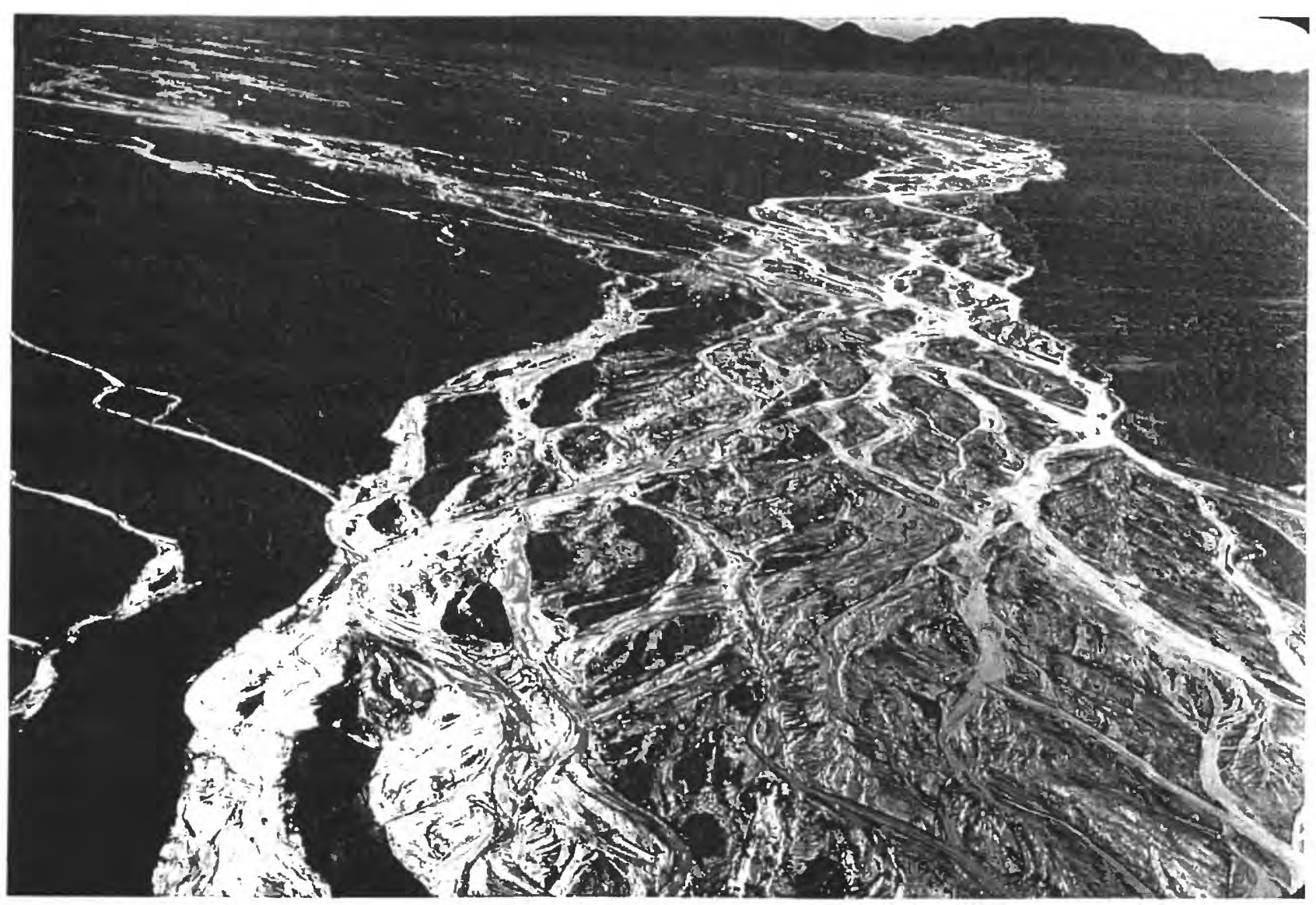

Fig. 3. Photograph of the Amargosa River in flood, August 20, 1977. Flooding caused by Hurricane Doreen. Photograph taken $125 \mathrm{~km}$ south of Beatty illustrates that in major storms all distributaries on the flood plain are in flood, not just the incised main channels. View east from between Saddle Peak Hills and Salt Spring Hills, California. 


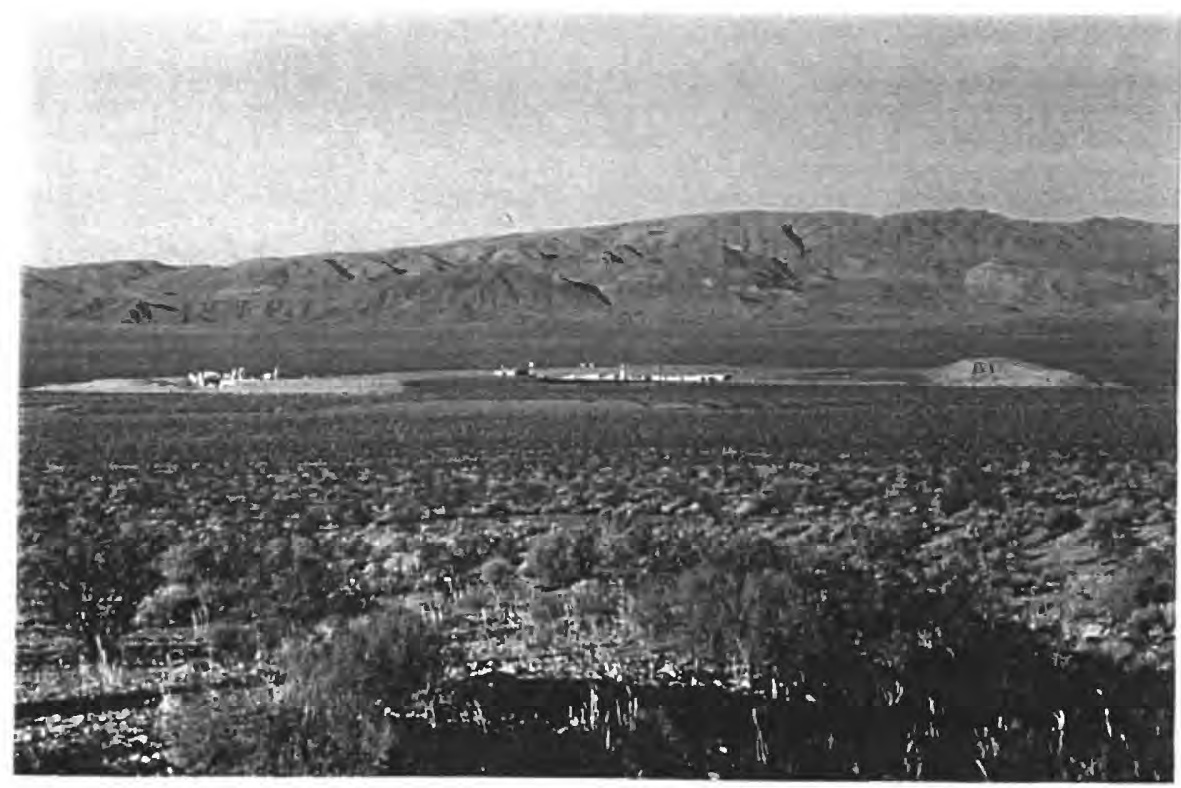

Fig. 4. View (westward) of the Beatty LLRW site from west flank of Bare Mountain, showing berm on north side of the facility. Funeral Mountains distant across the Amargosa River flood plain.

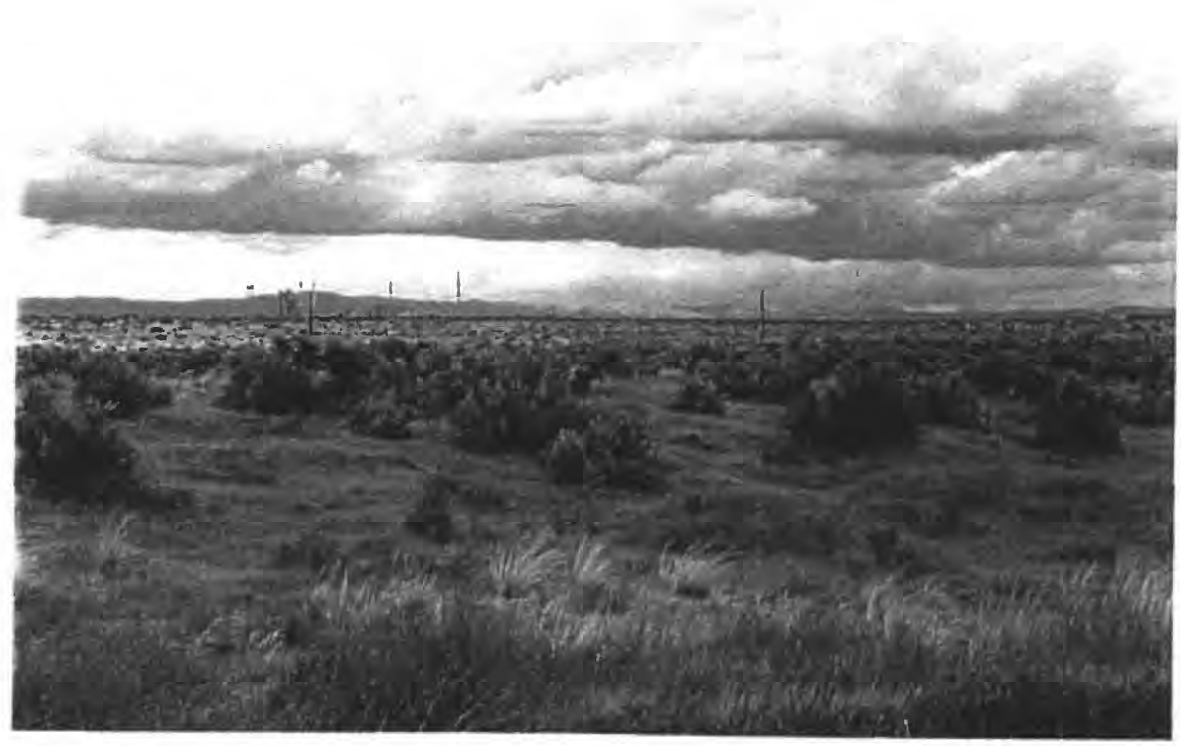

Fig. 6. View east across 200 West Area, Hanford Reservation, from U.S. Highway 240, showing general terrain and vegetation features shared by the Richland LLRW site farther east. 


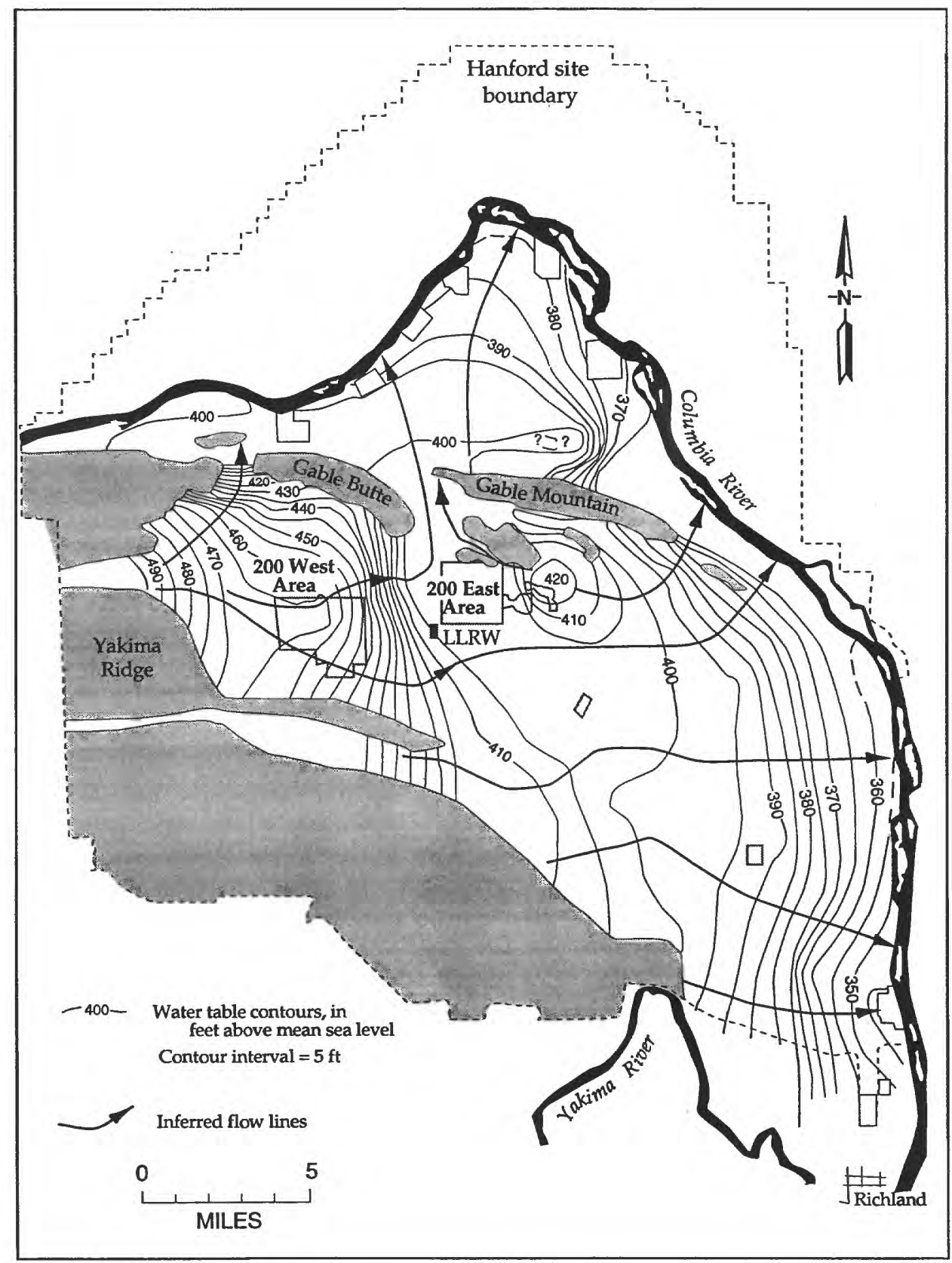

Modified from Lindsey and others (1994)

Fig. 5. Map of the Hanford Reservation site, Washington, showing location of the Richland LLRW site, the nearby 200 West and 200 East Areas, and contours on the water table. Generalized ground water flow paths shown by arrows. 


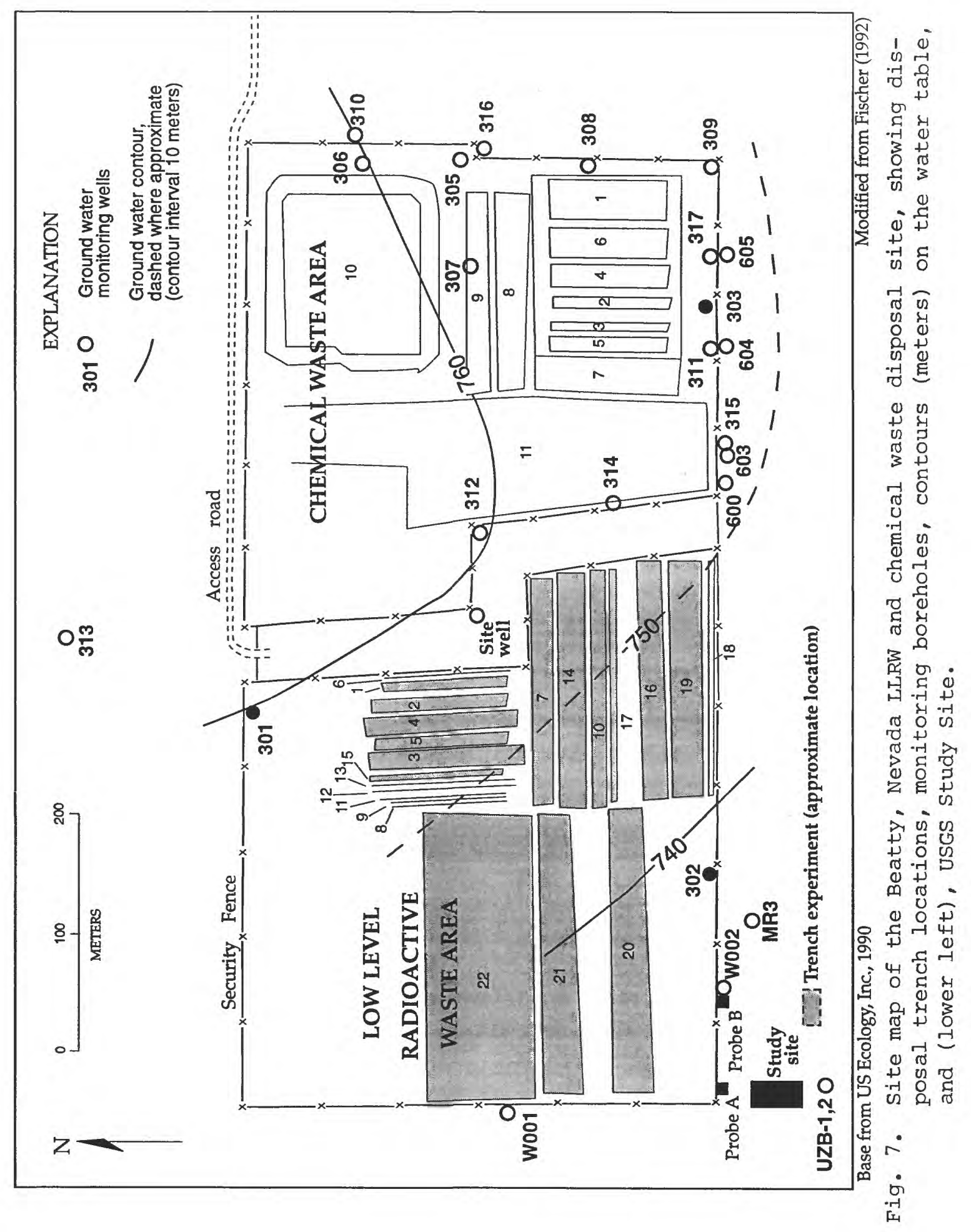




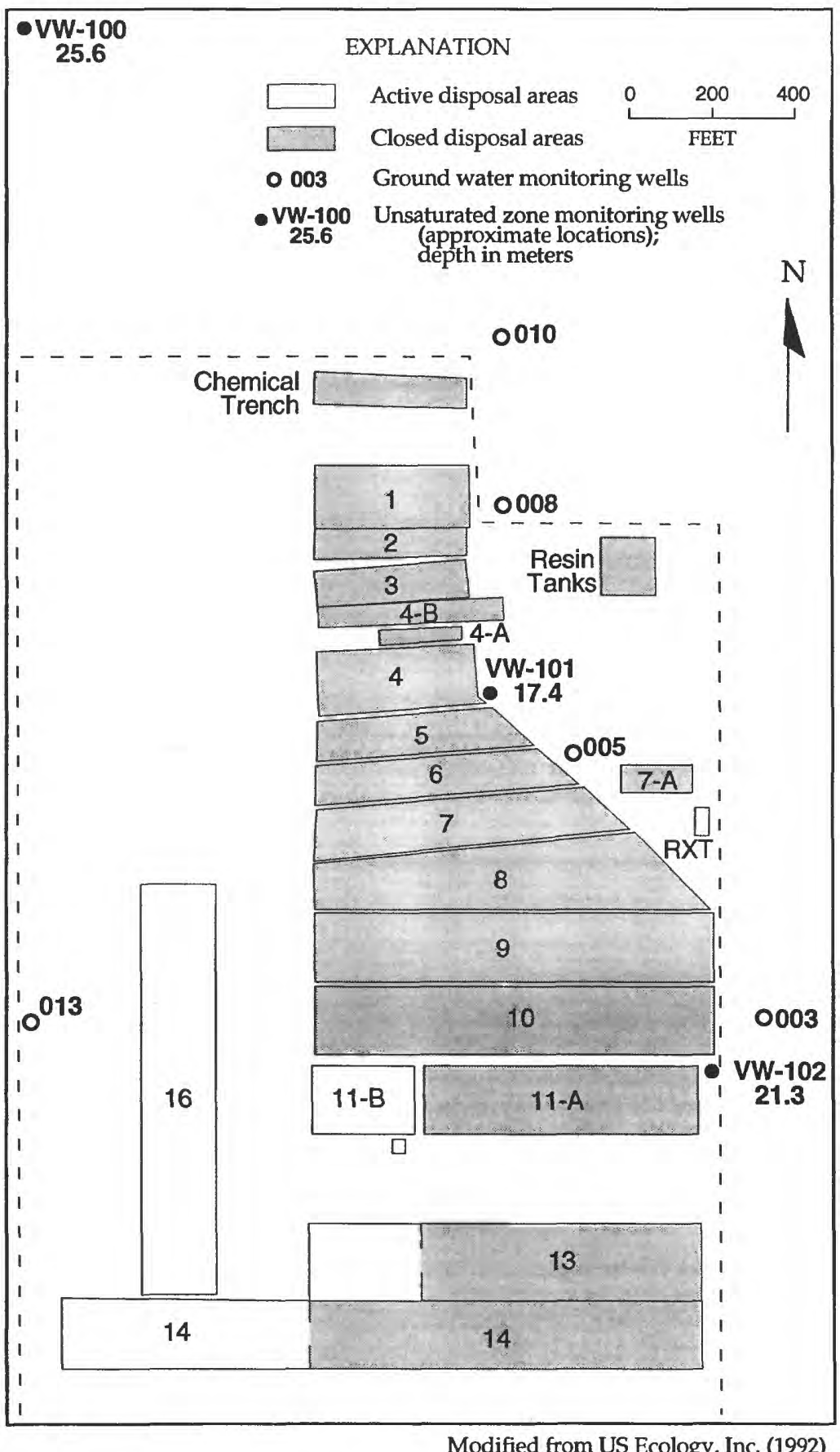

Fig. 8. Site map of the Richland LLRW site, showing locations of disposal trenches and resin tanks, and ground water (003-013) and unsaturated zone (VW-100 - VW-102) monitoring boreholes. 


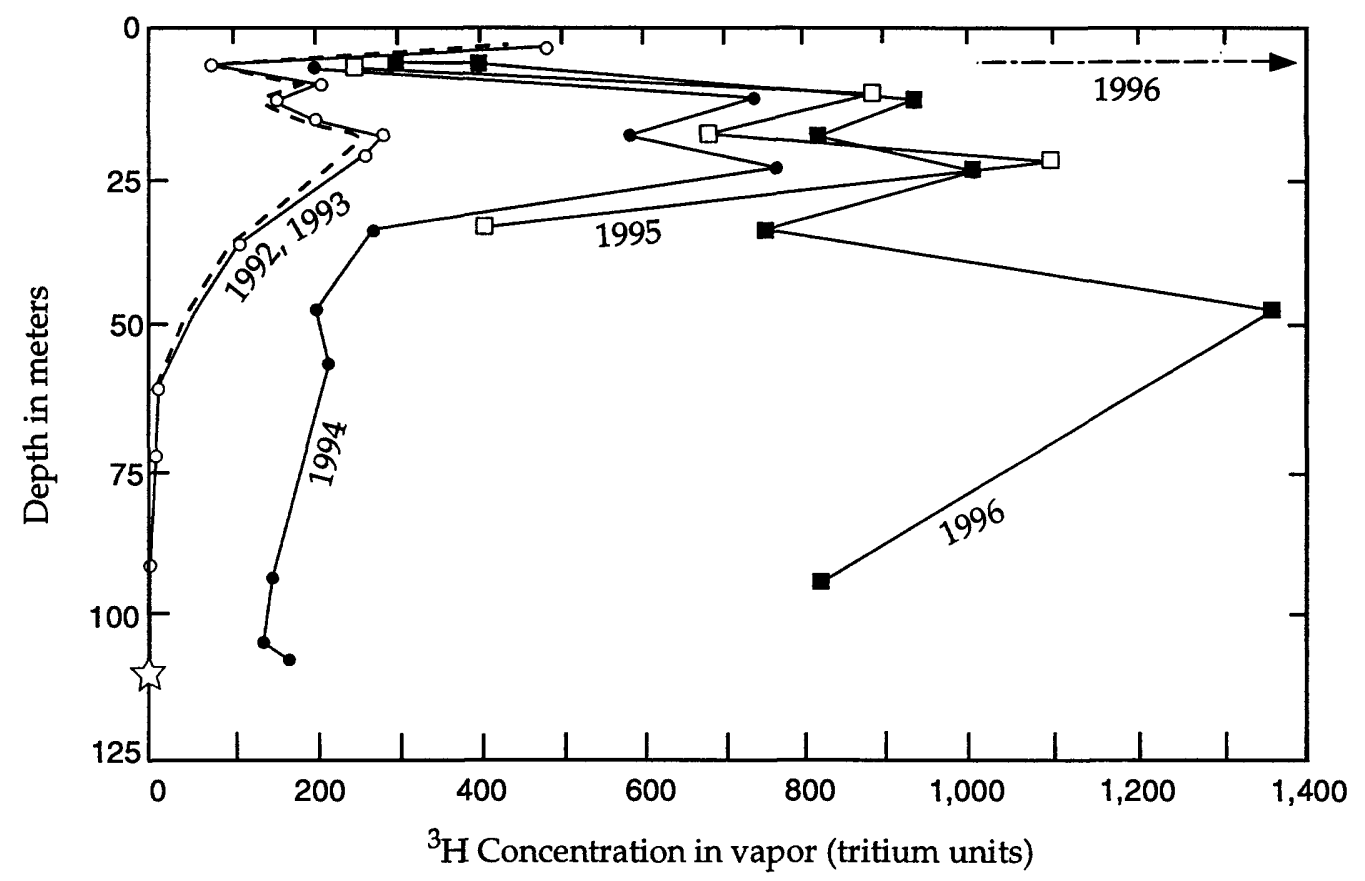

EXPLANATION

¿3 Ground water sampled Sept., 1993

- Pore water, UZB-2 cores, sampled Nov. 1992 and Sept. 1993

- - Vapor in equilibrium with pore water (calculated)

- Vapor, sampled April 1994

ㅁ Vapor, sampled July, 1995

- Vapor, sampled May, 1996

$\rightarrow 20,600$ Tritium units in vapor, $1.68 \mathrm{~m}$ depth, sampled May, 1996

Fig. 9. Tritium concentrations (tritium unit $=3.2 \mathrm{pCi} / \mathrm{L}$ ) in pore water from cores taken in 1992-93 and in vapor sampled in 1994-1996 from ports in borehole UZB-2 (see Fig. 7), Beatty Nevada site (from Prudic and others, 1997). 


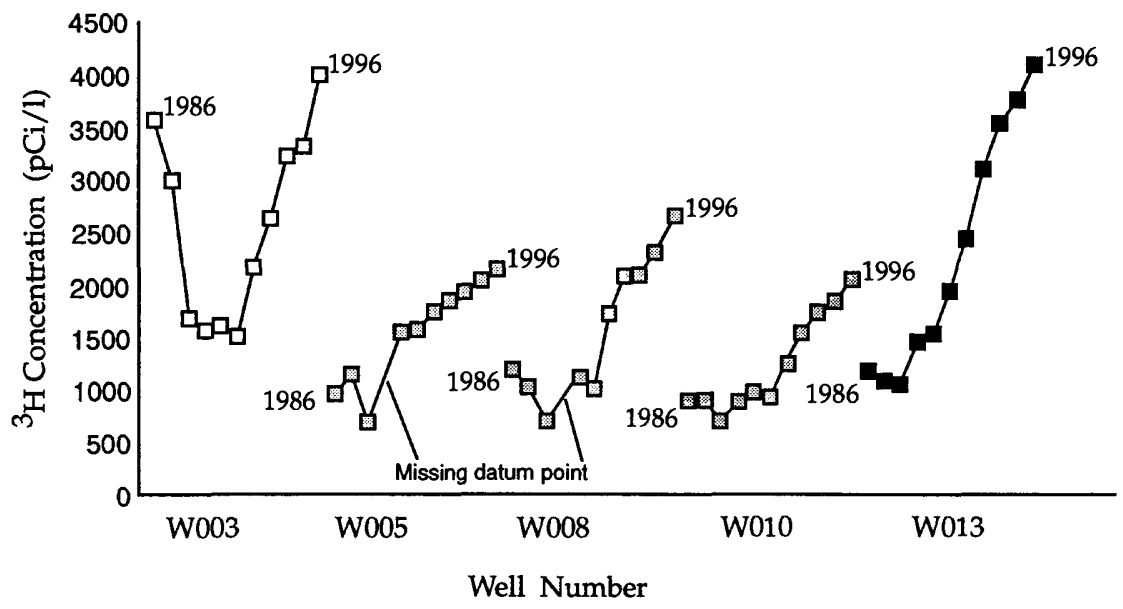

Fig. 10. Tritium concentrations $(\mathrm{pCi} / \mathrm{L})$ in ground water at five monitoring well sites annually from 1986 through 1996, Richland LLRW site. 


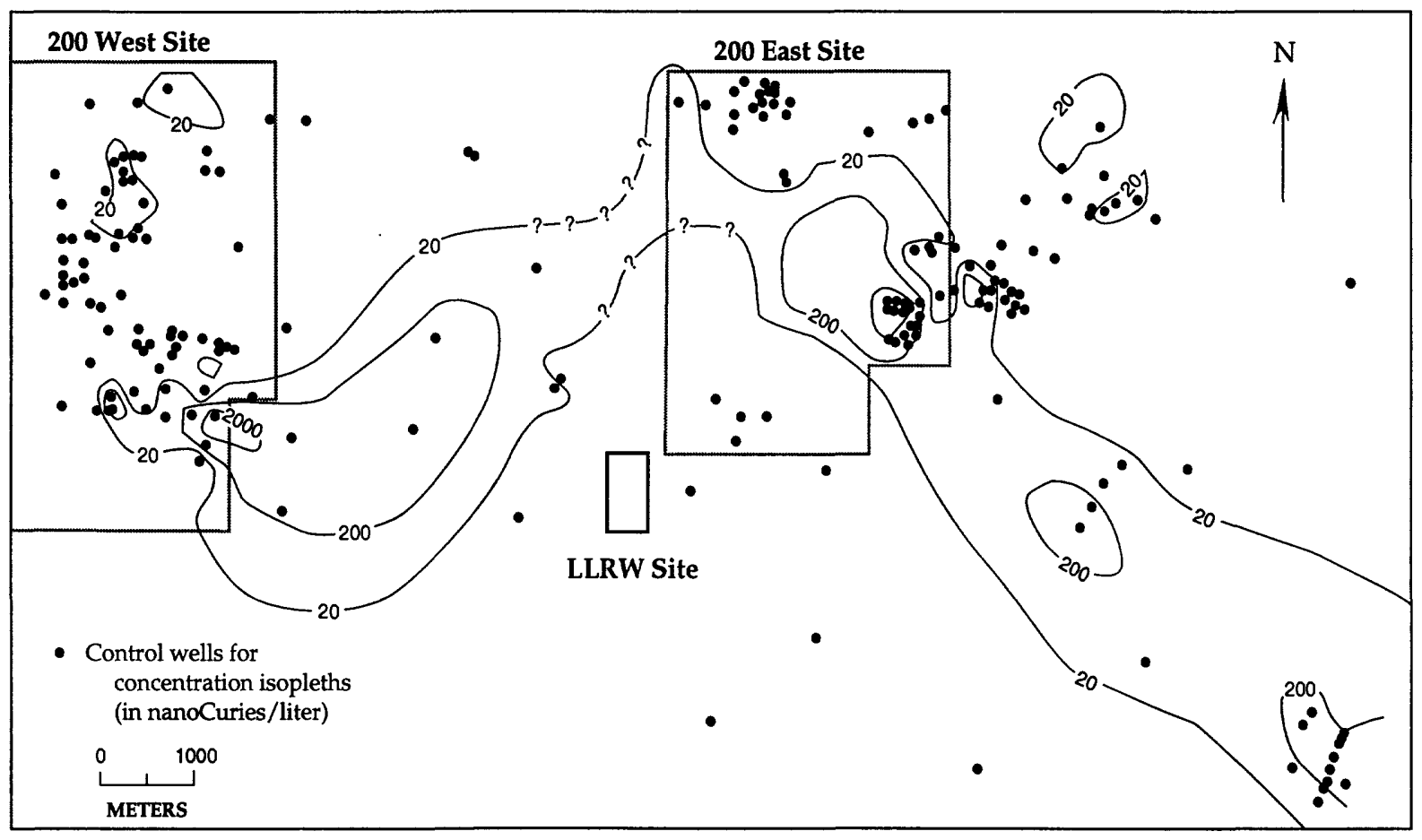

Modified from Connelly and others (1992), and Trent (1992)

Fig. 11. Tritium plume isopleths (nCi/L) in ground water, Hanford Reservation, relative to location of Richland LLRW site. Contaminant sources in 200 West and 200 East Areas. Modified from Connelly and others (1992) and Trent (1992). 


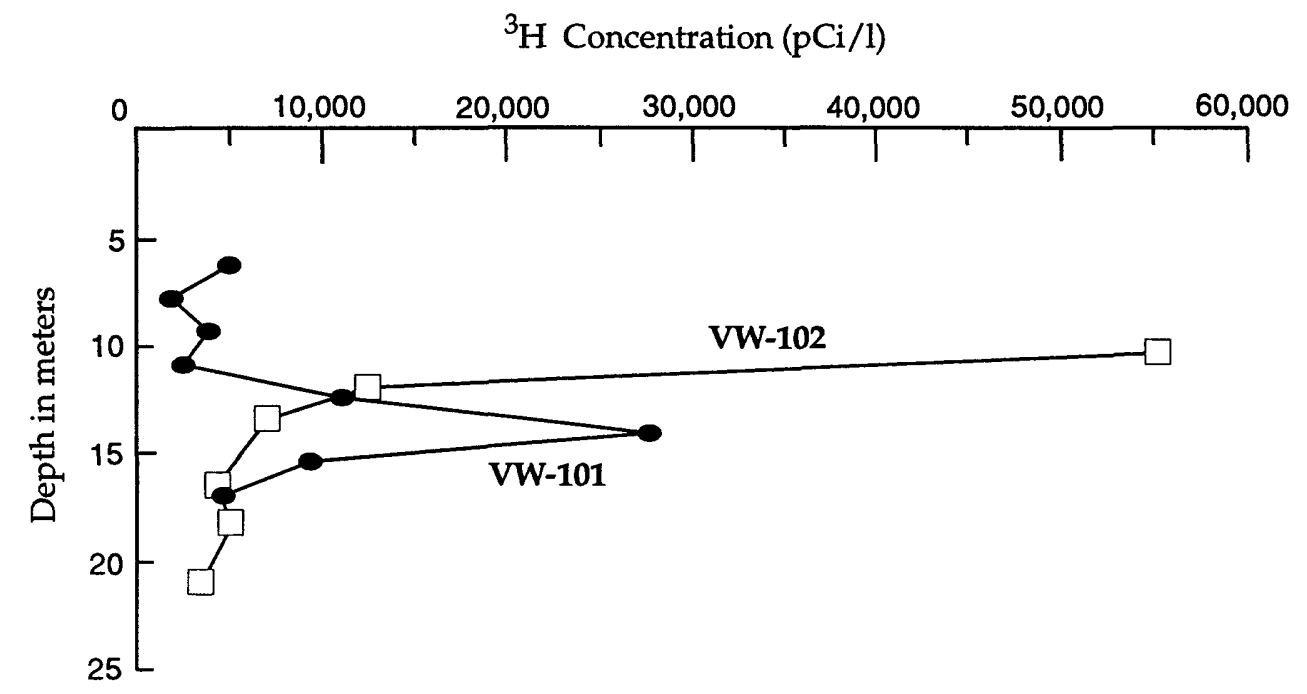

Fig. 12. Tritium concentrations $(\mathrm{pCi} / L)$ in pore water from unsaturated zone monitoring wells Vw-10I and Vw-102, Richland site. Samples collected in 1993 from lower $11 \mathrm{~m}$ of monitoring wells; this $11 \mathrm{~m}$ interval was screened (perforated casing) for subsequent vapor sampling (Table 9). 
Table 1. LLRW Trench Data, Beatty Site 1

\begin{tabular}{cccccccc}
\hline $\begin{array}{c}\text { Trench } \\
\text { No. }\end{array}$ & $\begin{array}{c}\text { Width } \\
(\mathrm{m})\end{array}$ & $\begin{array}{c}\text { Length } \\
(\mathrm{m})\end{array}$ & $\begin{array}{c}\text { Depth } \\
(\mathrm{m})\end{array}$ & $\begin{array}{c}\text { Volume } \\
\left(\mathrm{m}^{3}\right)\end{array}$ & $\begin{array}{c}\text { Date } \\
\text { Opened }\end{array}$ & $\begin{array}{c}\text { Date } \\
\text { Closed }\end{array}$ & $\begin{array}{c}\text { Time } \\
\text { Open } \\
(\mathrm{Mos})\end{array}$ \\
\hline 1 & 9.4 & 101.8 & 6.1 & 5,837 & Oct. 1962 & Jan. 1963 & 3 \\
2 & 12.5 & 115.5 & 6.1 & 8,807 & Jan. 1963 & Sept. 1963 & 8 \\
3 & 12.5 & 125.6 & 6.1 & 9,577 & Oct. 1963 & Aug. 1964 & 10 \\
4 & 17.4 & 129.8 & 6.1 & 13,777 & Sept. 1964 & June 1965 & 9 \\
5 & 12.2 & 114.6 & 6.1 & 8,529 & June 1965 & Feb. 1966 & 8 \\
6 & 1.5 & 105.5 & 1.8 & 285 & July 1965 & July 1966 & 11 \\
7 & 18.6 & 195.1 & 6.1 & 22,136 & Jan. 1966 & Sept. 1967 & 20 \\
8 & 1.2 & 109.4 & 1.8 & 236 & July 1966 & Oct. 1966 & 3 \\
9 & 1.5 & 109.1 & 1.8 & 295 & Mar. 1967 & May 1968 & 14 \\
10 & 12.2 & 203.0 & 6.1 & 15,107 & Aug. 1967 & Jan. 1970 & 29 \\
11 & 1.5 & 109.4 & 1.8 & 295 & May 1968 & Dec. 1968 & 7 \\
12 & 1.2 & 112.5 & 1.8 & 243 & Dec. 1968 & June 1969 & 6 \\
13 & 1.2 & 112.5 & 1.8 & 243 & June 1969 & Nov. 1969 & 5 \\
14 & 21.9 & 202.1 & 6.1 & 26,999 & Dec. 1969 & May 1973 & 41 \\
15 & 3.0 & 104.9 & 3.0 & 944 & Dec. 1969 & Jan. 1971 & 13 \\
16 & 22.3 & 206.0 & 6.1 & 28,022 & Jan. 1972 & Sept. 1974 & 31 \\
17 & 4.3 & 200.9 & 1.8 & 1,555 & Jan. 1972 & Jan. 1973 & 12 \\
18 & 3.0 & 203.3 & 1.8 & 1,098 & Jan. 1973 & Dec. 1973 & 11 \\
19 & 27.4 & 204.2 & 9.1 & 50,915 & Apr. 1974 & Jan. 1979 & 57 \\
20 & 34.1 & 240.8 & 10.7 & 87,861 & Feb. 1977 & Sept. 1979 & 31 \\
21 & 30.8 & 235.3 & 15.2 & 110,158 & Sept. 1979 & Apr. 1982 & 30 \\
22 & 91.4 & 243.8 & 15.2 & 338,706 & Mar. 1981 & Dec. 1992 & 141 \\
\hline
\end{tabular}

${ }^{1}$ Data from Jacobs Engineering Group (1987), Table 4-2, and date of site closure for No. 22. 
Table 2. Precipitation Estimates in and on Trenches at the Beatty LLRW Site ${ }^{1}$

\begin{tabular}{ccccc}
\hline Trench No. & $\begin{array}{c}\text { Vol. of PPT on } \\
\text { Open Trench } \\
\left(\mathrm{m}^{3}\right)\end{array}$ & $\begin{array}{c}\text { Vol. of PPT on } \\
\text { Trench after } \\
\text { Closure }\left(\mathrm{m}^{3}\right)\end{array}$ & $\begin{array}{c}\text { Total Vol. of } \\
\text { PPT in and on } \\
\text { Trench }\left(\mathrm{m}^{3}\right)\end{array}$ & $\begin{array}{c}\text { Time Elapsed } \\
\text { Before } \\
\text { Sampling }(\text { Yrs })\end{array}$ \\
\hline 1 & 27 & 2,694 & 2,721 & 31.2 \\
2 & 94 & 4,297 & 4,391 & 30.6 \\
3 & 117 & 4,168 & 4,286 & 29.7 \\
4 & 105 & 4,051 & 4,157 & 28.8 \\
5 & 94 & 3,958 & 4,051 & 28.2 \\
6 & 13 & 390 & 403 & 27.8 \\
7 & 435 & 6,937 & 7,372 & 26.6 \\
8 & 4 & 386 & 390 & 27.5 \\
9 & 16 & 364 & 381 & 25.9 \\
10 & 552 & 5,537 & 6,089 & 24.2 \\
11 & 8 & 356 & 364 & 25.3 \\
12 & 7 & 349 & 356 & 24.8 \\
13 & 6 & 343 & 349 & 24.4 \\
14 & 1,672 & 10,234 & 11,906 & 20.9 \\
15 & 38 & 817 & 855 & 23.2 \\
16 & 1,264 & 9,582 & 10,846 & 19.6 \\
17 & 65 & 2,376 & 2,442 & 21.2 \\
18 & 60 & 1,326 & 1,386 & 20.3 \\
19 & 2,907 & 9,332 & 12,238 & 15.2 \\
20 & 2,294 & 12,950 & 15,244 & 14.6 \\
21 & 1,971 & 9,459 & 11,430 & 12.0 \\
22 & 28,466 & 5,537 & 34,003 & 1.6 \\
\hline Total & 40,213 & 95,446 & 135,659 & \\
\hline
\end{tabular}

${ }^{1}$ Calculated on the basis of average annual precipitation of $108 \mathrm{~mm}$ (Andraski, 1996), trench dimensions, period of time trenches were open, and date of site closure (see Table 1).

${ }^{2}$ Sampling for tritium and carbon-14, April, 1994 (Striegl and others, 1996). 
Table 3. Trench Data, Richland LLRW Site ${ }^{1}$

\begin{tabular}{ccccc}
\hline $\begin{array}{c}\text { Trench } \\
\text { Number }\end{array}$ & $\begin{array}{c}\text { Date } \\
\text { Opened }\end{array}$ & $\begin{array}{c}\text { Date } \\
\text { Closed }\end{array}$ & $\begin{array}{c}\text { Trench } \\
\text { Depth } \\
(\mathrm{m})\end{array}$ & $\begin{array}{c}\text { Trench } \\
\text { Volume } \\
\left(\mathrm{m}^{3}\right)\end{array}$ \\
\hline 1 & $9 / 16 / 65$ & $9 / 12 / 66$ & $?$ & 1,829 \\
2 & $8 / 18 / 66$ & $11 / 30 / 71$ & $?$ & 4,193 \\
3 & $12 / 1 / 71$ & $3 / 31 / 75$ & $?$ & 3,669 \\
4 & $4 / 1 / 75$ & $8 / 10 / 78$ & 9.1 & 8,514 \\
$4 \mathrm{~A}$ & $4 / 30 / 82$ & $6 / 18 / 82$ & 6.1 & 344 \\
$4 \mathrm{~B}$ & $7 / 9 / 84$ & $8 / 23 / 85$ & 12.2 & 12 \\
5 & $4 / 29 / 78$ & $9 / 5 / 79$ & 9.1 & 13,762 \\
6 & $8 / 22 / 79$ & $6 / 10 / 80$ & 9.1 & 20,950 \\
7 & $10 / 29 / 82$ & $10 / 12 / 83$ & 12.8 & 30,811 \\
$7 \mathrm{~A}$ & $6 / 3 / 85$ & $7 / 16 / 85$ & 7.3 & 205 \\
8 & $5 / 5 / 80$ & $5 / 22 / 81$ & 10.7 & 31,695 \\
9 & $9 / 9 / 83$ & $11 / 30 / 84$ & 13.7 & 43,658 \\
10 & $5 / 5 / 81$ & $12 / 20 / 82$ & 13.7 & 61,849 \\
$11 \mathrm{~A}$ & $10 / 29 / 84$ & $11 / 7 / 85$ & 13.7 & 32,731 \\
$11 \mathrm{~B}$ & $10 / 29 / 84$ & open & 13.7 & open \\
13 & $7 / 29 / 85$ & $3 / 31 / 95$ & 13.7 & 35,336 \\
14 & $2 / 2 / 87$ & open & 13.7 & open \\
16 & $1 / 8 / 92$ & open & 13.7 & open \\
18 & $11 / 21 / 95$ & open & 13.7 & open \\
Tank Farm & $6 / 12 / 72$ & $5 / 4 / 87$ & 6.7 & 209 \\
Chemical & No info. & 1971 & $?$ & \\
\hline 11 & inf & & \\
\hline
\end{tabular}

1Data from Washington State Department of Health (G.

Robertson, written comm., 1997) 


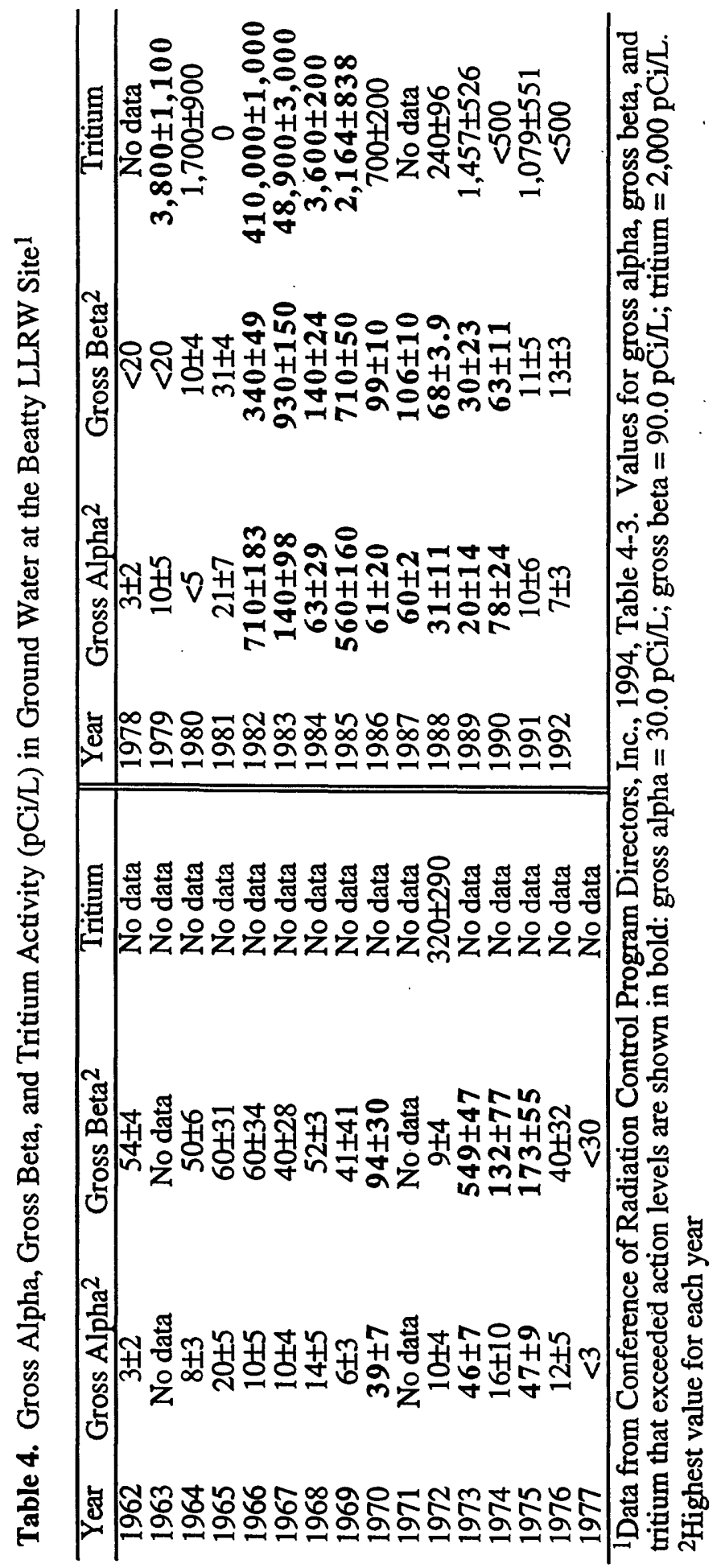


Table 5. Gross Alpha and Gross Beta (pCi/g) in Soils at the Beatty LLRW Site 1

\begin{tabular}{ccc||ccc}
\hline Year & Gross alpha $^{2}$ & Gross beta $^{2}$ & Year & Gross alpha $^{2}$ & Gross beta $^{2}$ \\
\hline 1962 & No data & No data & 1978 & $18 \pm 6$ & $60 \pm 24$ \\
1963 & No data & No data & 1979 & $31 \pm 13$ & $80 \pm 31$ \\
1964 & No data & No data & 1980 & $23 \pm 6.1$ & $\mathbf{9 0 \pm 1 6}$ \\
1965 & $1.9 \pm 0.63$ & $72 \pm 4.4$ & 1981 & $\mathbf{3 2 \pm 9 . 8}$ & $60 \pm 15$ \\
1966 & $2.7 \pm 1.2$ & $73 \pm 5.3$ & 1982 & $25 \pm 6$ & $66 \pm 18$ \\
1967 & $1.7 \pm 0.64$ & $3.5 \pm 0.34$ & 1983 & $24 \pm 7$ & $52 \pm 15$ \\
1968 & $2.94 \pm 0.41$ & $5.03 \pm 0.57$ & 1984 & $25 \pm 7$ & $52 \pm 15$ \\
1969 & $9.5 \pm 3.7$ & $37 \pm 4.1$ & 1985 & $16 \pm 3$ & $40 \pm 17$ \\
1970 & No data & No data & 1986 & $10.2 \pm 1.6$ & $9.6 \pm 1.0$ \\
1971 & $8.9 \pm 3.8$ & $80 \pm 4.9$ & 1987 & $1.3 \pm 0.3$ & $\mathbf{7 . 0}$ \\
1972 & $13 \pm 5$ & $\mathbf{1 0 8} \pm \mathbf{3 2}$ & 1988 & $5.7 \pm 1.1$ & $6.6 \pm 0.9$ \\
1973 & $\mathbf{6} \pm 3$ & $\mathbf{1 1 0} \pm \mathbf{4 0}$ & 1989 & $9.3 \pm 2.5$ & $21.5 \pm 1.3$ \\
1974 & $18.2 \pm 8.2$ & $\mathbf{2 5 3 . 6 \pm 1 1 1}$ & 1990 & $12.8 \pm 3$ & $51.5 \pm 7$ \\
1975 & $\mathbf{6 4} \pm \mathbf{1 5}$ & $\mathbf{6 1 4} \pm \mathbf{6 0}$ & 1991 & $3.5 \pm 1.0$ & $22.0 \pm 1.3$ \\
1976 & $\mathbf{4 2 \pm 7 . 7}$ & $\mathbf{2 5 7} \pm \mathbf{2 8}$ & 1992 & $5.4 \pm 2.7$ & $28.4 \pm 2.3$ \\
1977 & $20 \pm 6.1$ & $60 \pm 24$ & & & \\
\hline
\end{tabular}

${ }^{1}$ Data from Conference of Radiation Control Program Directors, Inc. (1994, Table 45). Values for gross alpha and gross beta that exceeded action levels are shown in bold: gross alpha $=30.0 \mathrm{pCi} / \mathrm{g}$; gross beta $=90.0 \mathrm{pCi} / \mathrm{g}$. Dry well samples from adjacent to the trenches, minimum of $3 \mathrm{~m}$ below trench bottom.

${ }^{2}$ Highest value for each year. 
Table 6. Gross Alpha and Gross Beta (pCi/g) and Tritium (pCi/L) in Vegetation at and Near the Beatty LLRW site ${ }^{1}$

\begin{tabular}{ccc||ccc}
\hline Year & Gross alpha & Gross beta & Year & Gross alpha $^{2}$ & Gross beta $^{2}$ \\
\hline 1962 & $0.73 \pm 0.32$ & $126 \pm 3.1$ & 1978 & $0.7 \pm 0.03$ & $36.9 \pm 9$ \\
1963 & No data & No data & 1979 & $0.7 \pm 0.6$ & $29.3 \pm 4.2$ \\
1964 & No data & No data & 1980 & $2.4 \pm 1$ & $50 \pm 5.1$ \\
1965 & $0.13 \pm 0.04$ & $21 \pm 0.5$ & 1981 & $9 \pm 4$ & $17.6 \pm 1.4$ \\
1966 & $0.9 \pm 0.45$ & $110 \pm 5.4$ & 1982 & $2.4 \pm 2$ & $30 \pm 4.9$ \\
1967 & $0.39 \pm 0.22$ & $8.0 \pm 0.4$ & 1983 & $6 \pm 3$ & $55.7 \pm 4.9$ \\
1968 & $0.16 \pm 0.04$ & $13.3 \pm 0.2$ & 1984 & $6.3 \pm 1.8$ & $15.5 \pm 2.3$ \\
1969 & $0.17 \pm 0.12$ & $31.3 \pm 0.27$ & 1985 & $7.2 \pm 1.3$ & $16 \pm 1$ \\
1970 & No data & No data & 1986 & $0.8 \pm 0.2$ & $5.8 \pm 0.2$ \\
1971 & $0.19 \pm 0.16$ & $2.8 \pm 0.3$ & 1987 & $5.3 \pm 2.7$ & $77.6 \pm 2.5$ \\
1972 & $1.4 \pm 1.0$ & $\mathbf{7 2 2} \pm 35$ & 1988 & $3.2 \pm 0.4$ & $10 \pm 0.3$ \\
1973 & $0.36 \pm 0.32$ & $27.2 \pm 3$ & 1989 & $0.6 \pm 0.2$ & $65.5 \pm 8.1$ \\
1974 & $3.8 \pm 4.1$ & $\mathbf{4 2 0} \pm 110$ & 1990 & $3.1 \pm 2.4$ & $16.3 \pm 3.6$ \\
1975 & $3.49 \pm 2.2$ & $146 \pm 30$ & 1991 & $0.5 \pm 0.2$ & $5.9 \pm 0.3$ \\
1976 & $9 \pm 3$ & $\mathbf{2 2 0} \pm \mathbf{2 0}$ & 1992 & $11.4 \pm 2.3$ & $48.9 \pm 2.8$ \\
1977 & $0.3 \pm 0.006$ & $39.6 \pm 14.5$ & & & \\
\hline \hline Year & Vegetation & Tritium & Year & Vegetation & Tritium \\
\hline \hline 1994 & 6 creosote shrubs & $9,472 \pm 160$ to & 1994 & 1 tumbleweed & $13,184 \pm 160$ \\
& SW corner & $31,360 \pm 288$ & & SW corner & \\
\hline
\end{tabular}

${ }^{1}$ Data from Conference of Radiation Control Program Directors, Inc. (1994, Table 47), tritium data from Striegl and others (1996). Values for gross alpha and gross beta that exceeded action levels are shown in bold: gross alpha $=20.0 \mathrm{pCi} / \mathrm{g}$; gross beta $=$ $200.0 \mathrm{pCi} / \mathrm{g}$.

${ }^{2}$ Highest value for each year. 
Table 7. Tritium $\left({ }^{3} \mathrm{H}\right)$ and Carbon- $14\left({ }^{14} \mathrm{C}\right)$, Unsaturated Zone Adjacent to and Near the Beatty LLRW Site ${ }^{1}$

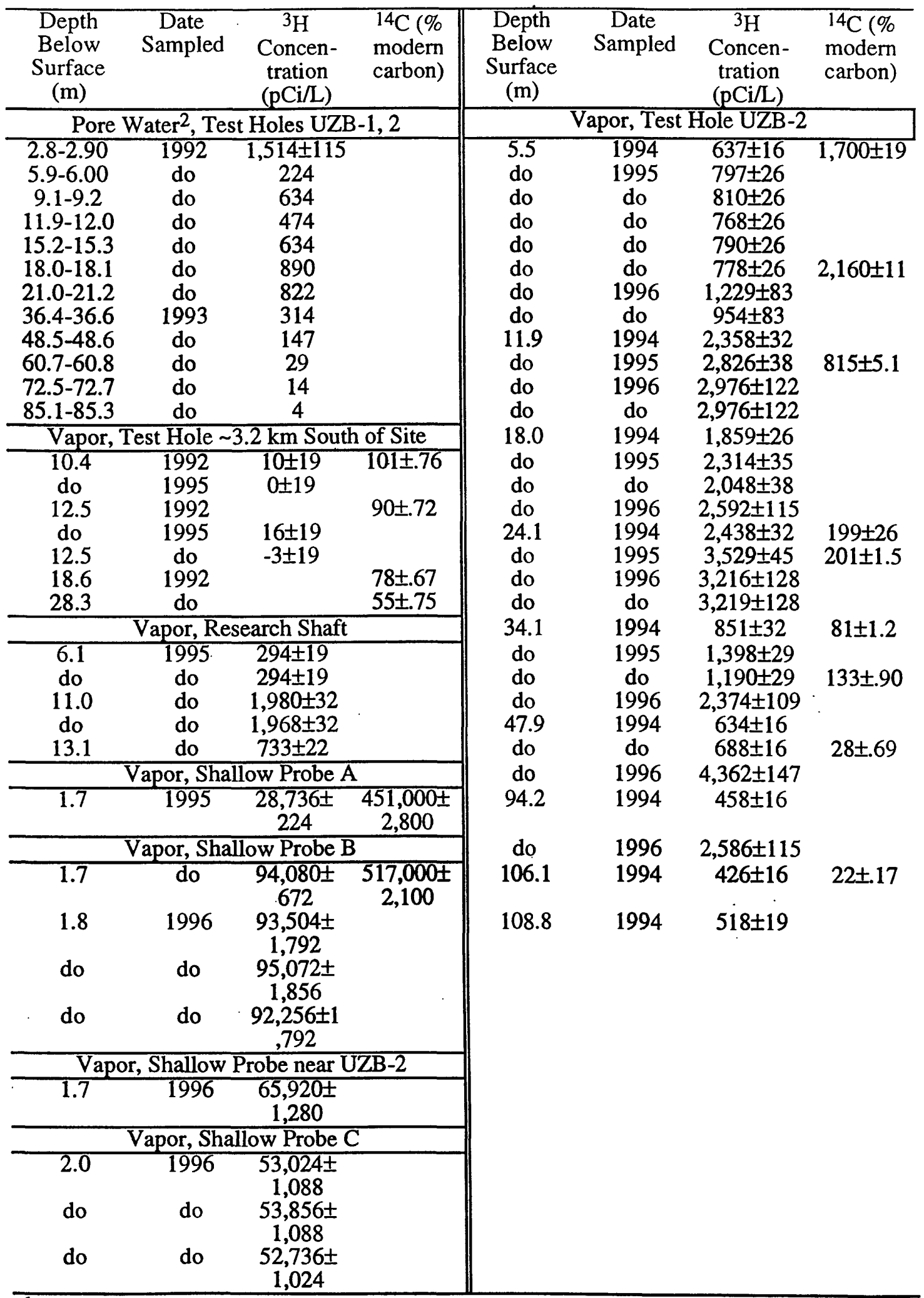

1Data from Prudic and Striegl (1995), Striegl and others (1996), Prudic and others (1997)

${ }^{2}$ Error is two-sigma counting uncertainty 
Table 8. Gross Alpha, Gross Beta, and Tritium Concentrations (pCi/L) in Ground Water, Richland LLRW Site ${ }^{1}$

\begin{tabular}{|c|c|c|c|c|c|}
\hline Constituent ${ }^{1}$ & Well \# 003 & Well \# 005 & Well \# 008 & Well \# 010 & Well \# 013 \\
\hline \multicolumn{6}{|c|}{1986} \\
\hline \multicolumn{6}{|l|}{ Gross Alpha } \\
\hline \multicolumn{6}{|l|}{ Gross Beta } \\
\hline Tritium & 3,550 & 952 & 1,180 & 884 & 1,190 \\
\hline \multicolumn{6}{|c|}{1987} \\
\hline \multicolumn{6}{|l|}{ Gross Alpha } \\
\hline \multicolumn{6}{|l|}{ Gross Beta } \\
\hline Tritium & 3,000 & 1,140 & 1,010 & 883 & 1,120 \\
\hline \multicolumn{6}{|c|}{1988} \\
\hline \multicolumn{6}{|l|}{ Gross Alpha } \\
\hline \multicolumn{6}{|l|}{ Gross Beta } \\
\hline Tritium & 1,680 & 690 & 690 & 690 & 1,090 \\
\hline \multicolumn{6}{|c|}{1989} \\
\hline \multicolumn{6}{|l|}{ Gross Alpha } \\
\hline \multicolumn{6}{|l|}{ Gross Beta } \\
\hline Tritium & 1,590 & - & - & 870 & 1,490 \\
\hline \multirow{2}{*}{$\begin{array}{l}\text { Gross Alpha } \\
\text { Gross Beta }\end{array}$} & \multicolumn{5}{|c|}{1990} \\
\hline & & & & & \\
\hline Tritium & 1,610 & 1,550 & 1,140 & 952 & 1,570 \\
\hline \multicolumn{6}{|c|}{1991} \\
\hline Gross Alpha & $<4.0 \pm 4.0$ & $<5.0 \pm 5.0$ & $6.0 \pm 2.0$ & $6.0 \pm 5.0$ & $<2.0 \pm 4.0$ \\
\hline Gross Beta & $7.0 \pm 1.0$ & $8.0 \pm 1.0$ & $8.0 \pm 1.0$ & $7.0 \pm 1.0$ & $8.0 \pm 1.0$ \\
\hline Tritium & $1,520 \pm 120$ & $1,570 \pm 120$ & $997 \pm 109$ & $928 \pm 105$ & $1,970 \pm 120$ \\
\hline \multicolumn{6}{|c|}{1992} \\
\hline \multicolumn{6}{|l|}{$\begin{array}{l}\text { Gross Alpha } \\
\text { Gross Beta }\end{array}$} \\
\hline $\begin{array}{l}\text { Gross Beta } \\
\text { Tritium }\end{array}$ & 2,150 & 1,740 & 1,707 & 1,270 & 2,450 \\
\hline \multicolumn{6}{|c|}{1993} \\
\hline Gross Alpha & $2.0 \pm .6$ & $2.0 \pm .8$ & $2.4 \pm .8$ & $\overline{<2}$ & $\overline{<2}$ \\
\hline Gross Beta & $7.1 \pm .8$ & $7.7 \pm .8$ & $7.1 \pm .7$ & $6.1 \pm .8$ & $7.6 \pm .8$ \\
\hline Tritium & $2,615 \pm 176$ & $1,847 \pm 148$ & $2,094 \pm 163$ & $1,553 \pm 148$ & $3,114 \pm 187$ \\
\hline \multicolumn{6}{|c|}{1994} \\
\hline Gross Alpha & $2.5 \pm .7$ & $1.6 \pm .6$ & $1.8 \pm 7$ & $1.4 \pm .6$ & $2.0 \pm .8$ \\
\hline $\begin{array}{c}\text { Gross Beta } \\
\text { Tritium }\end{array}$ & $\begin{array}{c}8.6 \pm .9 \\
3,250 \pm 177\end{array}$ & $\begin{array}{c}6.4 \pm .7 \\
1,920 \pm 139\end{array}$ & $\begin{array}{c}7.8 \pm .8 \\
2,091 \pm 151\end{array}$ & $\begin{array}{c}7.6 \pm .7 \\
1,728 \pm 137\end{array}$ & $\begin{array}{c}8.6 \pm .8 \\
3.559+178\end{array}$ \\
\hline \multicolumn{6}{|c|}{1995} \\
\hline Gross Alpha & $2.4 \pm .6$ & $1.8 \pm .6$ & $2.7 \pm 1.0$ & $1.9 \pm .8$ & $2.9 \pm 1.0$ \\
\hline Gross Beta & $11.7 \pm 1.4$ & $6.1 \pm 1.2$ & $7.0 \pm .7$ & $6.7 \pm 1.2$ & $8.7 \pm 1.4$ \\
\hline Tritium & $3,329 \pm 170$ & $2,025 \pm 154$ & $2,291 \pm 147$ & $1,838 \pm 136$ & $3,780 \pm 179$ \\
\hline \multicolumn{6}{|c|}{1996} \\
\hline Gross Alpha & $7.5 \pm .8$ & $2.1 \pm .7$ & $2.1 \pm .8$ & $1.5 \pm .8$ & $2.8 \pm .7$ \\
\hline Gross Beta & $7.5 \pm .8$ & $6.2 \pm .7$ & $7.6 \pm .8$ & $8.4 \pm .8$ & $8.4 \pm .8$ \\
\hline Tritium & $3,984 \pm 190$ & $2,121 \pm 150$ & $2,632 \pm 157$ & $2,039 \pm 157$ & $4,106 \pm 188$ \\
\hline
\end{tabular}




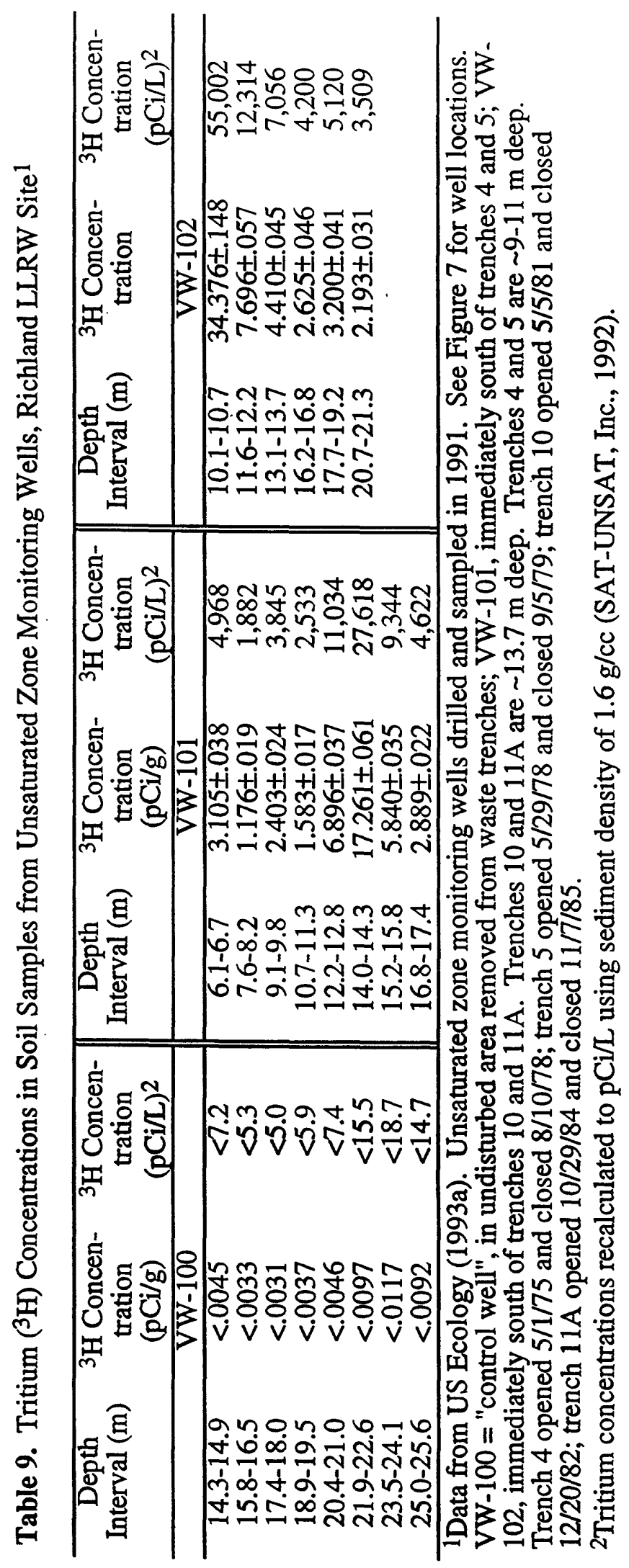


Table 10. Tritium Concentrations $\left(\mathrm{pCi} / \mathrm{L} \times 10^{3}\right)$ in Unsaturated Zone Vapor Samples, Richland LLRW Site ${ }^{1}$

\begin{tabular}{|c|c|c|c|c|}
\hline SS-100 & VW-100 & VW-101 & SS-102 & VW-102 \\
\hline \multicolumn{5}{|c|}{1993} \\
\hline & $1.4 \pm .13$ & $239 \pm 1.0$ & & $450 \pm 2.0$ \\
\hline \multicolumn{5}{|c|}{1994} \\
\hline $.1 \pm .08$ & $1.7 \pm 1.02$ & $283 \pm 1.0$ & $2.3 \pm .15$ & $497 \pm 1.0$ \\
\hline \multicolumn{5}{|c|}{1995} \\
\hline $2.1 \pm .15$ & $.9 \pm .90$ & $313 \pm 2.0$ & $5.9 \pm .22$ & $475 \pm 2.0$ \\
\hline \multicolumn{5}{|c|}{1996} \\
\hline $1.7 \pm .14$ & $7 \pm .12$ & $337 \pm 2.0$ & $10.9 \pm .29$ & $497 \pm 2.0$ \\
\hline $\begin{array}{l}\text { 1Data fror } \\
\text { from quar } \\
\text { condensec } \\
\text { Well VW } \\
\text { at Vadose } \\
\text { upper } 46\end{array}$ & site. S & $\begin{array}{l}\text { (1993b, 1994, 1995, } \\
\text { aents. SS-100, Solar } \\
\text { l upper } 46 \mathrm{~cm} \text { of soil a } \\
\text { 01, Solar Still, sampl } \\
\text { ell VW-101 site. SS- } \\
\text { dose Monitoring Wel }\end{array}$ & $\begin{array}{l}\text { 6), maxin } \\
\text { l, sample } \\
\text { adose Mc } \\
\text { upper 46 } \\
\text { Solar S } \\
\text { W-102 si }\end{array}$ & $\begin{array}{l}\text { im value } \\
\text { itoring } \\
\text { nof soil } \\
\text { l, sampled }\end{array}$ \\
\hline
\end{tabular}


Table 11. Tritium (pCi/L x 103) in Trench Cap Vegetation, Richland LLRW Site, 1987-19961

\begin{tabular}{|c|c|c|c|c|c|c|c|}
\hline Trench \# & ${ }^{3} \mathrm{H}$ & Trench \# & ${ }^{3} \mathrm{H}$ & Trench \# & ${ }^{3} \mathrm{H}$ & Trench \# & ${ }^{3} \mathrm{H}$ \\
\hline \multicolumn{4}{|c|}{1987} & \multicolumn{4}{|c|}{$1992^{2}$} \\
\hline 1 & $1.5 \pm .3$ & 5 & $39.4 \pm 2.1$ & 1 & $.7 \pm .10$ & 7 & $2.1 \pm .10$ \\
\hline 2 & $7.0 \pm 5.3$ & 8 & $19.8 \pm 1.2$ & 2 & $1.4 \pm .10$ & $7 \mathrm{~A}$ & $31.9 \pm .50$ \\
\hline 3 & $2.6 \pm .40$ & 9 & $47.2 \pm 2.6$ & 3 & $1.5 \pm .10$ & 8 & $25.4 \pm .40$ \\
\hline 4 & $3.8 \pm .40$ & 10 & $11.3 \pm .70$ & 4 & $3, .2 \pm .20$ & 9 & $26.4 \pm .40$ \\
\hline $4 \mathrm{~A}$ & $12.3 \pm .80$ & $11 \mathrm{~A}$ & $60.5 \pm 3.2$ & $4 \mathrm{~A}$ & $.8 \pm .11$ & 10 & $25.2 \pm .40$ \\
\hline $4 \mathrm{~B}$ & $2.3 \pm .30$ & & & $4 \mathrm{~B}$ & $1.1 \pm .10$ & $11 \mathrm{~A}$ & $173 \pm 1.0$ \\
\hline \multicolumn{4}{|c|}{1988} & 5 & $3.1 \pm .20$ & Resin Tank & $9.6 \pm .30$ \\
\hline 1 & $2.1 \pm .29$ & 6 & $27.5 \pm 2.1$ & 6 & $8.9 \pm .20$ & & \\
\hline 2 & $.9 \pm .2$ & 7 & $23.3 \pm 1.8$ & \multicolumn{4}{|c|}{1993} \\
\hline 3 & $4.1 \pm 4.4$ & $7 \mathrm{~A}$ & $1.2 \pm .22$ & 1 & $3.0 \pm .20$ & 7 & $3.8 \pm .10$ \\
\hline 4 & $106 \pm 7.9$ & 8 & $34.7 \pm 2.7$ & 2 & $1.0 \pm .10$ & $7 \mathrm{~A}$ & $7.4 \pm .20$ \\
\hline $4 \mathrm{~A}$ & $17.6 \pm 1.4$ & 9 & $6.1 \pm .58$ & 3 & $<.30$ & 8 & $1.3 \pm .10$ \\
\hline $4 \mathrm{~B}$ & $5.2 \pm .51$ & 10 & $1,510 \pm 110$ & 4 & $.7 \pm .10$ & 9 & $1.9 \pm .10$ \\
\hline 5 & $1,100 \pm 80.4$ & $11 \mathrm{~A}$ & $752 \pm 55$ & $4 \mathrm{~A}$ & $1.4 \pm .10$ & 10 & $4.1 \pm .20$ \\
\hline \multicolumn{4}{|c|}{1989} & 4B & $.3 \pm .10$ & $11 \mathrm{~A}$ & \multirow{3}{*}{$\begin{array}{c}15.3 \pm .30 \\
2.6 \pm .10\end{array}$} \\
\hline 4 & \multirow{3}{*}{$\begin{array}{c}103 \pm 7.7 \\
2.7 \pm .34 \\
4,270 \pm 311 \\
\end{array}$} & \multirow{3}{*}{$\begin{array}{c}6 \\
11 \mathrm{~A} \\
\text { Resin Tank } \\
\end{array}$} & \multirow{4}{*}{$\begin{array}{c}51.3 \pm 3.9 \\
1,040 \pm 75.8 \\
34.7 \pm 26.5\end{array}$} & 5 & $1.2 \pm .10$ & \multirow[t]{2}{*}{ Resin Tank } & \\
\hline \multirow{2}{*}{$\begin{array}{c}4 \mathrm{~B} \\
5\end{array}$} & & & & 6 & $1.0 \pm .10$ & & \\
\hline & & & & \multicolumn{4}{|c|}{1994} \\
\hline \multicolumn{3}{|c|}{1990} & & $\overline{7 \mathrm{~A}}$ & $.4 \pm .07$ & \multirow[t]{2}{*}{ Resin Tank } & \multirow[t]{2}{*}{$2.3 \pm .11$} \\
\hline \multirow{7}{*}{$\begin{array}{r}1 \\
2 \\
3 \\
4 \\
4 \mathrm{~A} \\
4 \mathrm{~B} \\
\end{array}$} & $.33 \pm .21$ & 5 & $466 \pm 34$ & 10 & $20.8 \pm .30$ & & \\
\hline & $.54 \pm .22$ & 6 & $815 \pm 60$ & \multicolumn{4}{|c|}{1995} \\
\hline & $18.6 \pm 1.5$ & 7 & $95.3 \pm 7.1$ & 1 & $12.6 \pm .26$ & 6 & $1.3 \pm .10$ \\
\hline & $24.1 \pm 1.9$ & 8 & $21.8 \pm 1.7$ & 2 & $6.9 \pm .23$ & 7 & $30 \pm .37$ \\
\hline & $2.4 \pm .33$ & 9 & $82.6 \pm 6.2$ & 3 & $5.2 \pm .16$ & 8 & $10.8 \pm .23$ \\
\hline & $5.0 \pm .51$ & Resin Tank & $8.5 \pm .76$ & 4 & $.5 \pm .06$ & 9 & $37.7 \pm .43$ \\
\hline & \multicolumn{3}{|c|}{1991} & $4 \mathrm{~A}$ & $.3 \pm .06$ & 10 & $17.7 \pm .29$ \\
\hline 1 & $2.3 \pm 1.7$ & $\overline{6}$ & $.2 \pm .07$ & 4B & $.3 \pm .06$ & $11 \mathrm{~A}$ & $16.2 \pm .29$ \\
\hline 2 & $2.0 \pm .75$ & 7 & $.9 \pm .21$ & 5 & $4.2 \pm .15$ & 13 & $212 \pm 2.1$ \\
\hline 3 & $2.0 \pm 1.2$ & 8 & $.9 \pm .38$ & \multicolumn{4}{|c|}{1996} \\
\hline 4 & $1.0 \pm .46$ & 9 & $.4 \pm .15$ & 1 & $4.2 \pm .20$ & 7 & $21.4 \pm .30$ \\
\hline $4 \mathrm{~A}$ & $1.1 \pm .65$ & $11 \mathrm{~A}$ & $.4 \pm .10$ & 2 & $8.4 \pm .20$ & $7 \mathrm{~A}$ & $.3 \pm .02$ \\
\hline 5 & $2.3 \pm .79$ & Resin Tank & $.6 \pm .24$ & 3 & $19.2 \pm .30$ & 8 & $1.6 \pm .10$ \\
\hline & & & & 4 & $.3 \pm .10$ & 9 & $30.5 \pm .40$ \\
\hline & & & & $4 \mathrm{~A}$ & $1.2 \pm .10$ & 10 & $18.6 \pm .16$ \\
\hline & & & & $4 \mathrm{~B}$ & $.1 \pm .10$ & $11 \mathrm{~A}$ & $12.0 \pm .12$ \\
\hline & & & & $\begin{array}{l}5 \\
6\end{array}$ & $\begin{array}{c}4 \pm .10 \\
144+90\end{array}$ & 13 & $5.2 \pm .08$ \\
\hline
\end{tabular}

1Data from US Ecology (1988, 1989, 1990b, 1991, 1992b, 1993a,b, 1994, 1995, 1996)

${ }^{2}$ From 1992 on, results are reported in $\mathrm{pCi} / \mathrm{g}$ of moisture derived from vegetation; conversion to $\mathrm{pCi} / \mathrm{L}$ here assumes moisture has a density of $1.0 \mathrm{~g} / \mathrm{cc}$. 